NBER WORKING PAPER SERIES

\title{
DOES SOCIAL SECURITY PRIVATIZATION PRODUCE EFFICIENCY GAINS?
}

\author{
Shinichi Nishiyama \\ Kent Smetters \\ Working Paper 11622 \\ http://www.nber.org/papers/w11622
}

\author{
NATIONAL BUREAU OF ECONOMIC RESEARCH \\ 1050 Massachusetts Avenue \\ Cambridge, MA 02138 \\ September 2005
}

Smetters research was supported by the U.S. Social Security Administration through a grant to the Michigan Retirement Research Consortium as part of the SSA Retirement Research Consortium. The opinions and conclusions expressed are solely those of the author(s) and do not represent the opinions or policy of SSA, any agency of the Federal Government, the MRRC or the CBO. Helpful comments were received from participants at the NBER Summer Institute Social Security Working Group (August 2004) and the AEA Annual Meeting (January 2005). The views expressed herein are those of the author(s) and do not necessarily reflect the views of the National Bureau of Economic Research.

(O2005 by Shinichi Nishiyama and Kent Smetters. All rights reserved. Short sections of text, not to exceed two paragraphs, may be quoted without explicit permission provided that full credit, including $\odot$ notice, is given to the source. 
Does Social Security Privatization Produce Efficiency Gains?

Shinichi Nishiyama and Kent Smetters

NBER Working Paper No. 11622

September 2005

JEL No. H0, H2, H3

\begin{abstract}
$\underline{\text { ABSTRACT }}$
While privatizing Social Security can improve labor supply incentives, it can also reduce risk sharing when households face uninsurable risks. We simulate a stylized 50-percent privatization using an overlapping-generations model where heterogenous agents with elastic labor supply face idiosyncratic earnings shocks and longevity uncertainty. When wage shocks are insurable, privatization produces about $\$ 21,900$ of new resources for each future household (growth adjusted over time) after all households have been fully compensated for their possible transitional losses. However, when wages are not insurable, privatization reduces efficiency by about $\$ 5,600$ per future household despite improved labor supply incentives.

We check the robustness of these results to different model specications and arrive at several surprising conclusions. First, privatization actually performs relatively better in a closed economy, where interest rates decline with capital accumulation, than in an open economy where capital can be accumulated without reducing interest rates. Second, privatization also performs relatively better when an actuarially-fair private annuity market does not exist than when it does exist. Third, introducing progressivity into the privatized system to restore risk sharing must be done carefully. In particular, having the government match private contributions on a progressive basis is not very effective at restoring risk sharing -- too much matching actually harms efficiency. However, increasing the progressivity of the remaining traditional system is very effective at restoring risk sharing, thereby allowing partial privatization to produce efficiency gains of $\$ 2,700$ per future household.
\end{abstract}

Shinichi Nishiyama

CBO

Ford House Office Building, Room 468

$2^{\text {nd }}$ and D Streets, SW

Washington, DC 20515-6295

shinichi.nishiyama@cbo.gov

Kent Smetters

The Wharton School

3620 Locust Walk, 3302 SH-DH

Philadelphia, PA 19104-6302

and NBER

smetters@wharton.upenn.edu 


\section{Introduction}

It has been known for some time that shutting down ("privatizing") a pay-as-you-go social security system would simply reallocate resources between generations when all economic variables are deterministic and labor supply is inelastic. In particular, no new resources would be created in present value once the "winners" have fully compensated the "losers." Allowing for elastic labor supply as well as various risks that are difficult to insure in the private market, however, changes things considerably.

On one hand, privatization could produce efficiency gains by reducing the effective tax rate on labor supply. Social Security’s payroll taxes distort labor supply decisions because the program redistributes resources both across and within generations. Across generations, retiree benefits are financed on a pay-as-you-go basis with taxes on younger workers. When the economy grows slower than the interest rate (i.e., is dynamically efficient), a worker with average earnings receives less that one dollar in present value in future benefits for each dollar they contribute - the difference is an effective tax. This tax services the implicit debt inherited from past generations who received more from Social Security than they paid. Within generations, the U.S. Social Security system is progressive by giving a household with a lower average index of monthly wages (AIME) a larger Social Security benefit relative to their AIME (i.e., a larger "replacement rate"). Contributions by households with higher-than average lifetime earnings, therefore, are effectively used to subsidize the contributions by households with lower-than average lifetime earnings. This redistribution increases effective marginal tax rates on households with AIME's above the economy-wide average while reducing effective marginal tax rates on households with smaller AIME's.

On the other hand, the U.S. Social Security system also provides two sources of risk sharing that could be reduced by privatization. First, the progressive benefit formula shares wage shocks among participants that are difficult to insure in the private market. Privatization, therefore, could reduce this insurance unless it were complemented with some form of redistribution. Second, Social Security pays benefits until the beneficiary and spouse dies rather than over a fixed number of years. To the extent that longevity uncertainty is also

\footnotetext{
${ }^{1}$ See, e.g., Breyer (1989), Feldstein (1995), Geanakoplos, Mitchell and Zeldes (1998), Murphy and Welch (1998), Mariger (1999), Shiller (1999), and Diamond and Orszag (2003).
} 
difficult to insure privately, privatization could also reduce this annuity protection.

\subsection{Overview of Our Approach}

Determining the overall change in efficiency from privatization requires simulation analysis. We use a heterogeneous overlapping-generations model in which agents with elastic labor supply face idiosyncratic earnings shocks and longevity uncertainty. The economy's entire transition path after privatization is calculated, allowing us to determine the efficiency gain or loss from this reform. ${ }^{2}$ All households across generations and income classes receive rebates or are taxed by exactly enough to return their expected remaining lifetime utility to their pre-reform levels. If the net amount of new resources remaining after these rebates and taxes is positive, then privatization produces an efficiency gain; if negative, an efficiency loss. Following Auerbach and Kotlikoff (1987), new net resources (positive or negative) are distributed to future households in equal amounts (growth adjusted over time).

In our particular policy experiment, we consider a stylized partial privatization where households immediately begin to redirect 50 percent of their payroll tax into private accounts. Traditional Social Security benefits, though, are reduced slowly across cohorts and eventually reach 50 percent of their original scheduled value for the youngest workers alive at the time of reform. Cash flow deficits, therefore, emerge during the transition which are financed with a consumption tax; Kotlikoff, Smetters, and Walliser (2001) used a deterministic model to show that consumption tax financing of the transition creates fewer distortions to labor supply and capital accumulation than income or wage tax financing. ${ }^{3}$

\subsection{Summary of Our Findings}

We find that privatization can substantially improve labor supply incentives: When wage shocks are assumed to be insurable in the private market, our stylized partial privatization

\footnotetext{
${ }^{2}$ The insurance value of pay-as-you-go Social Security has also been investigated by İmrohoroğlu, İmrohoroğlu, and Joines (1995) and Conesa and Krueger (1999). İmrohoroğlu et al. focus on steady states and find that the value of risk sharing is outweighed by the reduction in capital. Conesa and Krueger consider whether a majority of the population would support privatization. Our analysis finds that while privatization typically raises long-run welfare it often fails to increase efficiency due to larger losses to transitional generations.

${ }^{3}$ Nishiyama and Smetters (2004) show that a consumption tax, though, might be less efficient than a progressive income tax in the presence of idiosyncratic shocks. Still, using a proportional increase in the income tax, as examined in KSW, would not overturn our key results.
} 
produces new net resources equal to $\$ 21,900$ per future household in our benchmark model. However, when, more realistically, wages are not insurable, privatization reduces efficiency by about $\$ 5,600$ per future household despite improving labor supply incentives. This loss occurs even though privatization substantially increases the welfare of those born in the long run by increasing the capital stock.

The efficiency loss that we calculate when wages are not insurable, though, makes three key assumptions that might appear at first to be biased against privatization. Several surprising insights emerge, however, as we investigate each of these assumptions more closely.

First, our benchmark economy is closed to international capital flows. As a result, capital accumulation after privatization reduces interest rates, discouraging more accumulation. If, instead, capital could flow across borders then more capital could be accumulated with no reduction in the rate of return to saving.

However, interestingly, we find that the efficiency losses from partial privatization are even larger (equal to about $\$ 6,600$ per future household) in a small open economy version of our model that allows for perfect international capital flows. To be sure, privatization leads to substantially more capital accumulation in this case. But, for the purpose of determining effciency gains, the higher interest rate in the open economy case, relative to privatization in the closed economy, also means that it is more costly to borrow against the long-run gains from privatization in order to compensate households alive during the transition that would otherwise lose from privatization. This finding emphasizes the fact that gains to macroeconomic variables alone are not necessarily good metrics for inferring efficiency gains.

Second, our benchmark calculations assume that a private annuity market does not exist, and so the pre-reform Social Security system not only provides insurance against wage uncertainty but against longevity as well. Households, therefore, must guard against outliving their resources after privatization by relying more on precautionary saving, which is less efficient at smoothing consumption across states than insurance markets when shocks are idiosyncratic.

However, rather surprisingly, we find that allowing for an actuarially-fair private annuity market also increases efficiency losses (about $\$ 7,200$ per future household) relative to our benchmark privatization simulation. This result can be mostly traced to the relative smaller 
amount of precautionary saving after privatization when private annuity markets exist. The larger interest rate in this case increases the cost at which compensation can be made across generations. Less precautionary savings and lower labor supply also reduce the tax bases relative to the benchmark privatization, thereby increasing the income tax rates that are required to fund the rest of government.

Third, our benchmark partial privatization does not explicitly include any mechanism that shares idiosyncratic wage shocks that were previously partially insured under Social Security. Since private markets generally do not exist for insuring wages, households must again rely on more precautionary saving, which is less efficient than insurance.

We, therefore, also simulate privatization where the government matches contributions made by poorer households; the match is financed by increasing general-revenue income taxes proportionally. This match is permanent across time but phased out linearly across income classes so that a household with median income receives no match. A match equal to 10 percent of income at a low level of income is indeed effective at reducing the efficiency loss to about $\$ 4,400$ per future household, but a 20-percent match actually increases the loss to $\$ 9,900$. This non-monotonic behavior is due to the trade-off between risk sharing and labor supply distortions: some match is beneficial but is dominated by distortions at higher tax rates. In fact, there is no match rate that allows privatization to produced efficiency gains; alternative designs of contribution matching (e.g., without a phase-out) performed even worse.

Finally and related, we show that simply increasing the progressivity of the smaller Social Security program that remains after partial privatization performs quite well at restoring risk sharing and can even lead to overall efficiency gains after privatization (about $\$ 2,700$ per future household). Compared to contribution matching, this alternative produces smaller marginal tax rates because Social Security benefits are computed based on lifetime earnings whereas the match is based on contemporaneous earnings.

\subsection{Outline of Rest of the Paper}

The rest of the paper is as follows: Section 2 describes the model; Section 3 explains the calibration of the model; Section 4 presents results from various privatization simulations; 
and Section 5 concludes the paper. The Appendices explain the computational algorithm in more detail and contain various calibration information.

\section{Model}

Our model has three sectors: heterogeneous households with elastic labor supply; a competitive representative firm with constant-returns-to-scale production technology; and a government with a full commitment technology. Like most previous analyses of Social Security reform, our model's pre-reform neoclassical economy is stationary by construction, and so we don't capture the effects of projected demographic changes. ${ }^{4}$ We, however, are only interested in comparing the efficiency of gains from privatization against the baseline, not examining the implications of demographics. We used a similar model in Nishiyama and Smetters (2004) to analyze potential reforms of the federal income tax; the model in the current paper adds a Social Security system which requires an additional state variable in order to track a household's historical average earnings.

\subsection{The Household Sector}

Households are heterogeneous with respect to the following variables: age, $i$; working ability, $e_{i}$ (measured by hourly wages); beginning-of-period wealth holdings, $a_{i}$; and, average historical earnings, $b_{i}$, that determine their Social Security benefits. Each year, a large number (normalized to unity) of new households of age 20 enter the economy. Population grows at a constant rate, $\nu$. A household of age $i$ observes an idiosyncratic working ability shock, $e_{i}$, at the beginning of each year and chooses its optimal consumption $c_{i}$, working hours $h_{i}$, and end-of-period wealth holding $a_{i+1}$, taking as given the government's policy schedule and future factor prices. ${ }^{5}$ At the end of each year, a fraction of households die according to standard mortality rates; no one lives beyond age 109. For simplicity, all households represent two-earner married couples of the same age.

\footnotetext{
${ }^{4}$ We are aware of only a few papers, including De Nardi, İmrohoroğlu and Sargent (1999), Kotlikoff, Smetters and Walliser (2001), and Nishiyama (2004), that attempt to capture the effect of non-stationary demographics on baseline factor prices.

${ }^{5}$ Because there are no aggregate shocks in the present model, households can perfectly foresee these factor prices and policy variables, using the current distribution of households and the current policy variables. Yet, their own future working ability and mortality are uncertain.
} 


\subsubsection{The Household's Problem}

Let $\mathbf{s}_{i}$ denote the state of an age $i$ household,

$$
\mathbf{s}_{i}=\left(i, e_{i}, a_{i}, b_{i}\right)
$$

where $i \in I=\{20, \ldots, 109\}$ is the household's age, $e_{i} \in E=\left[e^{\min }, e^{\max }\right]$ is its working ability (the hourly wage), $a_{i} \in A=\left[a^{\min }, a^{\max }\right]$ is its beginning-of-period wealth, and $b_{i} \in B=\left[b^{\min }, b^{\max }\right]$ is its average historical earnings for Social Security purposes. ${ }^{6}$

Let $\mathbf{S}_{t}$ denote the state of the economy at the beginning of year $t$,

$$
\mathbf{S}_{t}=\left(x_{t}\left(\mathbf{s}_{i}\right), W_{L S, t}, W_{G, t}\right)
$$

where $x_{t}\left(\mathbf{s}_{i}\right)$ is the joint distribution of households where $\mathbf{s}_{i} \in I \times E \times A \times B$. $W_{L S, t}$ is the beginning-of-period net wealth held by the Lump-Sum Redistribution Authority (LSRA), which as described below, is used to determine the efficiency gain or loss from privatization. $W_{G, t}$ is the net wealth of the rest of the government.

Let $\boldsymbol{\Psi}_{t}$ denote the government policy schedule known at the beginning of year $t$,

$$
\mathbf{\Psi}_{t}=\left\{W_{L S, s+1}, W_{G, s+1}, C_{G, s}, \tau_{I, s}(.), \tau_{P, s}(.), \tau_{C, s}, \operatorname{tr}_{S S, s}\left(\mathbf{s}_{i}\right), \operatorname{tr}_{L S, s}\left(\mathbf{s}_{i}\right)\right\}_{s=t}^{\infty},
$$

where $C_{G, s}$ is government consumption, $\tau_{I, s}($.$) is an income tax function, \tau_{P, s}($.$) is a payroll$ tax function for Social Security (OASDI), $\tau_{C, s}$ is a consumption tax rate, $\operatorname{tr}_{S S, s}\left(\mathbf{s}_{i}\right)$ is a Social Security benefit function, and $\operatorname{tr}_{L S, s}\left(\mathbf{s}_{i}\right)$ is an LSRA wealth redistribution function. The specifications of these functions are described below.

The household's problem is

$$
v\left(\mathbf{s}_{i}, \mathbf{S}_{t} ; \mathbf{\Psi}_{t}\right)=\max _{c_{i}, h_{i}} u_{i}\left(c_{i}, h_{i}\right)+\beta(1+\mu)^{\alpha(1-\gamma)} \phi_{i} E\left[v\left(\mathbf{s}_{i+1}, \mathbf{S}_{t+1} ; \mathbf{\Psi}_{t+1}\right) \mid e_{i}\right]
$$

\footnotetext{
${ }^{6}$ The average historical earnings are used to calculate the Social Security benefits of each household. The variable $b_{i}$ approximates the average indexed monthly earnings (AIME) multiplied by 12 as of age $i$.
} 
subject to

$$
\begin{aligned}
a_{i+1} & =\frac{1}{1+\mu}\left\{w_{t} e_{i} h_{i}+\left(1+r_{t}\right)\left(a_{i}+\operatorname{tr}_{L S, t}\left(\mathbf{s}_{i}\right)\right)\right. \\
& -\tau_{I, t}\left(w_{t} e_{i} h_{i}, r_{t}\left(a_{i}+\operatorname{tr}_{L S, t}\left(\mathbf{s}_{i}\right)\right), \operatorname{tr}_{S S, t}\left(\mathbf{s}_{i}\right)\right) \\
& \left.-\tau_{P, t}\left(w_{t} e_{i} h_{i}\right)+\operatorname{tr}_{S S, t}\left(\mathbf{s}_{i}\right)-\left(1+\tau_{C, t}\right) c_{i}\right\} \geq a_{i+1, t}^{\min }\left(\mathbf{s}_{i}\right), \\
a_{20} & =0, \quad a_{i \in\{65, \ldots, 110\}} \geq 0,
\end{aligned}
$$

where the utility function, $u_{i}($.$) , takes the Cobb-Douglas form nested within a time-separable$ isoelastic specification,

$$
u\left(c_{i}, h_{i}\right)=\frac{\left\{\left(\left(1+n_{i} / 2\right)^{-\zeta} c_{i}\right)^{\alpha}\left(h_{i}^{\max }-h_{i}\right)^{1-\alpha}\right\}^{1-\gamma}}{1-\gamma}
$$

$\gamma$ is the coefficient of relative risk aversion; $n_{i}$ is the number of dependent children at the parents' age $i$; $\zeta$ is the "adult equivalency scale" that converts the consumption by children into their adult equivalent amounts; and, $h_{i}^{\max }$ is the maximum working hours.

The constant $\beta$ is the rate of time preference; $\phi_{i}$ is the survival rate at the end of age $i ; w_{t}$ is the wage rate per efficiency unit of labor (accordingly, $w_{t} e_{i} h_{i}$ is total labor compensation at age $i$ in time $t$ ); and, $r_{t}$ is the rate of return to capital. Individual variables of the model are normalized by the exogenous rate of labor augmenting technological change, $\mu$. Our choice for $u_{i}($.$) is consistent with the conditions that are necessary for the existence of a long-run$ steady state in the presence of constant population growth. Hence, $\mu$ is also equal to the percapita growth rate of output and capital in steady state. The term $\beta(1+\mu)^{\alpha(1-\gamma)}$, therefore, is the growth-adjusted rate of time preference.

$a_{i+1, t}^{\min }\left(\mathbf{s}_{i}\right)$ is the state-contingent minimum level of end-of-period wealth that is sustainable, that is, even if the household receives the worst possible shocks in future working abilities. $^{7}$ At the beginning of the next period, the state of this household when private annuity

\footnotetext{
${ }^{7}$ In particular, $a_{i+1, t}^{\min }\left(\mathbf{s}_{i}\right)$ is allowed to be negative but cannot exceed in magnitude the present value of the worst possible future labor income stream at maximum working hours. Although not shown explicitly in equation (2) in order to save on notation, any borrowing (i.e., $a_{i+1}<0$ ) by an agent age $i$ at time $t$ must be done at rate $r_{t} / \phi_{i}$ in order cover the chance that they will die before repaying their loan.
} 
markets do not exist becomes

$$
\mathbf{s}_{i+1}=\left(i+1, e_{i+1}, a_{i+1}+q_{t}, b_{i+1}\right)
$$

where $q_{t}$ denotes accidental bequests that a household receives at the end of the period. In the presence of perfect annuity markets, the household's state in the next period is instead

$$
\mathbf{s}_{i+1}=\left(i+1, e_{i+1}, a_{i+1} / \phi_{i}, b_{i+1}\right) .
$$

The average historical earnings for this household, $b_{i}$, follows the following process,

$$
b_{i+1}= \begin{cases}0 & \text { if } i \leq 24 \\ \frac{1}{i-24}\left\{(i-25) b_{i} \frac{w_{t}}{w_{t-1}}+\min \left(w_{t} e_{i} h_{i} / 2, w e h_{t}^{\max }\right)\right\} & \text { if } 25 \leq i \leq 59 \\ b_{i} /(1+\mu) & \text { if } i \geq 60\end{cases}
$$

where $w e h_{t}^{\max }$ is the Old-Age, Survivors, and Disability Insurance (OASDI) tax cap, which is $\$ 80,400$ in 2001 . For simplicity, the model assumes that the highest 35 years of earnings correspond to between ages 25 and $59 .{ }^{8}$

\subsubsection{The Measure of Households}

Let $x_{t}\left(\mathbf{s}_{i}\right)$ denote the measure of households, and let $X_{t}\left(\mathbf{s}_{i}\right)$ be the corresponding cumulative measure. The measure of households is adjusted by the steady-state population growth rate, $\nu$. The population of age 20 households is normalized to unity in the baseline economy along the balanced growth path, that is,

$$
\int_{E} \mathrm{~d} X_{t}\left(20, e_{20}, 0,0\right)=1
$$

Let $\mathbf{1}_{[a=y]}$ be an indicator function that returns 1 if $a=y$ and 0 if $a \neq y$. Then, the law of motion of the measure of households is

$$
\begin{aligned}
x_{t+1}\left(\mathbf{s}_{i+1}\right) & =\frac{\phi_{i}}{1+\nu} \int_{E \times A \times B} \mathbf{1}_{\left[a_{i+1}=a_{i+1}\left(\mathbf{s}_{i}, \mathbf{S}_{t} ; \mathbf{\Psi}_{t}\right)+q_{t}\right]} \\
& \times \mathbf{1}_{\left[b_{i+1}=b_{i+1}\left(w_{t} e_{i} h_{i}\left(\mathbf{s}_{i}, \mathbf{S}_{t} ; \mathbf{\Psi}\right), b_{i}\right)\right]} \pi_{i, i+1}\left(e_{i+1} \mid e_{i}\right) \mathrm{d} X_{t}\left(\mathbf{s}_{i}\right),
\end{aligned}
$$

\footnotetext{
${ }^{8}$ U.S. Social Security benefits are computed on the basis of the highest 35 years of earnings, up to age 60 . We assume that these years occur between ages 25 and 59 to avoid 34 additional state variables.
} 
where $\pi_{i, i+1}$ denotes the transition probability of working ability from age $i$ to age $i+1$.

\subsubsection{Distribution of Bequests}

The aggregate value of accidental bequests each period is deterministic in our model because all risks are idiosyncratic and, therefore, uncorrelated across households. Accidental bequests could, therefore, be simply distributed equally and deterministically across all surviving households, as in some other papers. That approach, however, suffers from two shortcomings. First, households would anticipate receiving a bequest with certainty, thereby artificially crowding out their pre-bequest savings. This savings reduction would be mitigated if bequests were random. Second, empirically, the inequality of bequests is important in generating a realistic measure of wealth inequality.

Our alternative strategy, therefore, distributes bequests randomly to surviving workingage households. Each household receives a bequest $q_{t}$ with constant probability $\eta$ :

$$
\begin{aligned}
q_{t} & =\frac{\sum_{i=20}^{109}\left(1-\phi_{i}\right) \int_{E \times A \times B} a_{i+1}\left(\mathbf{s}_{i}, \mathbf{s}_{t} ; \mathbf{\Psi}_{t}\right) \mathrm{d} X_{t}\left(\mathbf{s}_{i}\right)}{\sum_{i=20}^{109}\left(1-\phi_{i}\right) \int_{E \times A \times B} \mathrm{~d} X_{t}\left(\mathbf{s}_{i}\right)}, \\
\eta & =\frac{\sum_{i=20}^{109}\left(1-\phi_{i}\right) \int_{E \times A \times B} \mathrm{~d} X_{t}\left(\mathbf{s}_{i}\right)}{\sum_{i=20}^{64} \phi_{i} \int_{E \times A \times B} \mathrm{~d} X_{t}\left(\mathbf{s}_{i}\right)}
\end{aligned}
$$

where $q_{t}$ is the average wealth left by deceased households and $\eta$ is the ratio of deceased household to the surviving working-age households.

\subsection{Government}

Government tax revenue consists of federal income tax $T_{I, t}$, payroll tax for Social Security (OASDI) $T_{P, t}$, and consumption tax $T_{C, t}$. These revenues are

$$
\begin{aligned}
& T_{I, t}=\sum_{i=20}^{109} \int_{E \times A \times B} \\
& \tau_{I, t}\left(w_{t} e_{i} h_{i}\left(\mathbf{s}_{i}, \mathbf{S}_{t} ; \mathbf{\Psi}_{t}\right), r_{t}\left(a_{i}+t r_{L S, t}\left(\mathbf{s}_{i}\right)\right), \operatorname{tr}_{S S, t}\left(\mathbf{s}_{i}\right)\right) \mathrm{d} X_{t}\left(\mathbf{s}_{i}\right), \\
& T_{P, t}=\sum_{i=20}^{109} \int_{E \times A \times B} \tau_{P, t}\left(w_{t} e_{i} h_{i}\left(\mathbf{s}_{i}, \mathbf{S}_{t} ; \mathbf{\Psi}_{t}\right)\right) \mathrm{d} X_{t}\left(\mathbf{s}_{i}\right),
\end{aligned}
$$




$$
T_{C, t}=\sum_{i=20}^{109} \int_{E \times A \times B} \tau_{C, t} c_{i}\left(\mathbf{s}_{i}, \mathbf{S}_{t} ; \mathbf{\Psi}_{t}\right) \mathrm{d} X_{t}\left(\mathbf{s}_{i}\right) .
$$

Social Security (OASDI) benefit expenditure $T r_{S S, t}$ is

$$
\operatorname{Tr}_{S S, t}=\sum_{i=20}^{109} \int_{E \times A \times B} \operatorname{tr}_{S S, t}\left(\mathbf{s}_{i}\right) \mathrm{d} X_{t}\left(\mathbf{s}_{i}\right) .
$$

The law of motion of the government wealth (normalized by productivity growth and population growth) is

$$
\begin{aligned}
W_{G, t+1} & =\frac{1}{(1+\mu)(1+\nu)} \\
& \times\left\{\left(1+r_{t}\right) W_{G, t}+T_{I, t}+T_{P, t}+T_{C, t}-\operatorname{Tr}_{S S, t}-C_{G, t}\right\},
\end{aligned}
$$

where $C_{G, t}$ is government consumption.

\subsection{Measuring Efficiency Gains}

We follow Auerbach and Kotlikoff (1987) by measuring efficiency gains from Social Security privatization using a Lump-Sum Redistribution Authority that compensates households who would otherwise lose from reform. ${ }^{9}$ To be clear, the LSRA is not being proposed as an actual government institution that attempts to produce Pareto-improving policy changes. Instead, it is simply a hypothetical mechanism that allows us to measure the standard Hicksian efficiency gains in general equilibrium associated with privatization.

To see how the LSRA works, suppose that a new policy is announced at the beginning of period 1. First, the LSRA makes a lump-sum compensating variation transfer or tax, $\operatorname{tr}_{C V, 1}\left(\mathbf{s}_{i}\right)$, to each living household of age $i$ to return its expected remaining lifetime utility at state $\mathbf{s}_{i}$ to its pre-reform level in the baseline (pre-reform) economy. Next, the LSRA makes a lump-sum transfer or tax, $\operatorname{tr}_{C V, t}\left(\mathbf{s}_{20}\right)$, to each future household (born in periods 2, $3, \ldots)$ to make it as well off as in the baseline economy, conditional on its initial state at age 20. Thus far, however, the net present value of these taxes and transfers across living and future households will generally not sum to zero. So, finally, the LSRA makes an additional lump-sum transfer (tax), $\Delta t r$, to each future household so that the net present value across

\footnotetext{
${ }^{9}$ We, however, extend the Auerbach and Kotlikoff approach to a heterogeneous-agent environment.
} 
all transfers is zero. For illustrative purposes, we assume, like Auerbach and Kotlikoff, that these additional transfers are uniform across future generations on a growth-adjusted basis. The lump-sum transfers made by the LSRA, therefore, are

$$
\operatorname{tr}_{L S, t}\left(\mathbf{s}_{i}\right)= \begin{cases}\operatorname{tr}_{C V, t}\left(\mathbf{s}_{i}\right) & \text { if } t=1 \\ \operatorname{tr}_{C V, t}\left(\mathbf{s}_{i}\right)+\Delta t r & \text { if } t>1 \text { and } i=20 \\ 0 & \text { otherwise }\end{cases}
$$

If $\Delta t r>0$ then privatization has produced net new resources and so we say that this reform "increases efficiency." Conversely, if $\Delta t r<0$ then privatization "reduces efficiency."

The aggregate net lump-sum transfers / taxes to living households at time $t, \operatorname{Tr}_{L S, t}$, is

$$
\operatorname{Tr}_{L S, t}=\sum_{i=20}^{109} \int_{E \times A \times B} \operatorname{tr}_{L S, t}\left(\mathbf{s}_{i}\right) \mathrm{d} X_{t}\left(\mathbf{s}_{i}\right) .
$$

The law of motion of the LSRA wealth (normalized by productivity growth and population growth), therefore, is

$$
W_{L S, t+1}=\frac{1}{(1+\mu)(1+\nu)}\left(1+r_{t}\right)\left(W_{L S, t}-\operatorname{Tr}_{L S, t}\right) .
$$

\subsection{Aggregation and Production}

National wealth $W_{t}$ is the sum of total private wealth, government net wealth $W_{G, t}$, and LSRA net wealth $W_{L S, t}$. Total labor supply $L_{t}$ is measured in efficiency units

$$
\begin{aligned}
W_{t} & =\sum_{i=20}^{109} \int_{E \times A \times B} a_{i} \mathrm{~d} X_{t}\left(\mathbf{s}_{i}\right)+W_{L S, t}+W_{G, t}, \\
L_{t} & =\sum_{i=20}^{109} \int_{E \times A \times B} e_{i} h_{i}\left(\mathbf{s}_{i}, \mathbf{S}_{t} ; \mathbf{\Psi}_{t}\right) \mathrm{d} X_{t}\left(\mathbf{s}_{i}\right) .
\end{aligned}
$$

In a closed economy, capital stock is equal to national wealth, that is, $K_{t}=W_{t}$, and gross national product $Y_{t}$ is determined by a constant-returns-to-scale production function,

$$
Y_{t}=F\left(K_{t}, L_{t}\right)
$$


The profit-maximizing condition for this competitive firm is

$$
\begin{aligned}
& F_{K}\left(K_{t}, L_{t}\right)=r_{t}+\delta, \\
& F_{L}\left(K_{t}, L_{t}\right)=w_{t},
\end{aligned}
$$

where $\delta$ is the depreciation rate of capital.

In a small open economy, factor prices, $r_{t}^{*}$ and $w_{t}^{*}$ are fixed at international levels, and domestic capital stock $K_{D, t}$ and labor supply $L_{t}$ are determined so that the firm's profit maximizing condition satisfies,

$$
\begin{aligned}
F_{K}\left(K_{D, t}, L_{t}\right) & =r_{t}^{*}+\delta, \\
F_{L}\left(K_{D, t}, L_{t}\right) & =w_{t}^{*}
\end{aligned}
$$

Gross domestic product $Y_{D, t}$ is determined by the production function,

$$
Y_{D, t}=F\left(K_{D, t}, L_{t}\right)
$$

and gross national product $Y_{t}$ is determined by

$$
Y_{t}=\left(r_{t}^{*}+\delta\right) W_{t}+w_{t}^{*} L_{t} .
$$

Net foreign investment is shown by the difference between national wealth and domestic capital stock, that is, $W_{t}-K_{D, t}$.

\subsection{Recursive Competitive Equilibrium}

Definition Recursive Competitive Equilibrium: Let $\mathbf{s}_{i}=\left(i, e_{i}, a_{i}, b_{i}\right)$ be the individual state of households, let $\mathbf{S}_{t}=\left(x_{t}\left(\mathbf{s}_{i}\right), W_{L S, t}, W_{G, t}\right)$ be the state of the economy, and let $\mathbf{\Psi}_{t}$ be the government policy schedule known at the beginning of year $t$,

$$
\mathbf{\Psi}_{t}=\left\{W_{L S, s+1}, W_{G, s+1}, C_{G, s}, \tau_{I, s}(.), \tau_{P, s}(.), \tau_{C, s}, \operatorname{tr}_{S S, s}\left(\mathbf{s}_{i}\right), \operatorname{tr}_{L S, s}\left(\mathbf{s}_{i}\right)\right\}_{s=t}^{\infty} .
$$

A series of factor prices $\left\{r_{s}, w_{s}\right\}_{s=t}^{\infty}$, accidental bequests $\left\{q_{s}\right\}_{s=t}^{\infty}$, the policy variables $\left\{W_{L S, s+1}, W_{G, s+1}, C_{G, s}, \tau_{C, s}, \operatorname{tr}_{L S, s}\left(\mathbf{s}_{i}\right)\right\}_{s=t}^{\infty}$, the parameters of policy functions $\left\{\varphi_{s}\right\}_{s=t}^{\infty}$, 
Table 1: Common Parameters

\begin{tabular}{lll}
\hline Coefficient of relative risk aversion & $\gamma$ & 2.0 \\
Capital share of output & $\theta$ & 0.30 \\
Depreciation rate of capital stock & $\delta$ & 0.047 \\
Long-term real growth rate & $\mu$ & 0.018 \\
Population growth rate & $\nu$ & 0.010 \\
Probability of receiving bequests & $\eta$ & 0.0161 \\
Total factor productivity ${ }^{1}$ & $A$ & 0.949 \\
\hline 1. Total factor productivity is chosen so that $w$ equals 1.0.
\end{tabular}

the value function of households $\left\{v\left(\mathbf{s}_{i}, \mathbf{S}_{s} ; \mathbf{\Psi}_{s}\right)\right\}_{s=t}^{\infty}$, the decision rule of households

$$
\left\{\mathbf{d}\left(\mathbf{s}_{i}, \mathbf{S}_{s} ; \mathbf{\Psi}_{s}\right)\right\}_{s=t}^{\infty}=\left\{c_{i}\left(\mathbf{s}_{i}, \mathbf{S}_{s} ; \mathbf{\Psi}_{s}\right), h_{i}\left(\mathbf{s}_{i}, \mathbf{S}_{s} ; \mathbf{\Psi}_{s}\right), a_{i+1}\left(\mathbf{s}_{i}, \mathbf{S}_{s} ; \mathbf{\Psi}_{s}\right)\right\}_{s=t}^{\infty}
$$

and the measure of households $\left\{x_{s}\left(\mathbf{s}_{i}\right)\right\}_{s=t}^{\infty}$, are in a recursive competitive equilibrium if, in every period $s=t, \ldots, \infty$, each household solves the utility maximization problem (1)-(6) taking $\Psi_{t}$ as given; the firm solves its profit maximization problem, the capital and labor market conditions (17)-(20) clear, and the government policy schedule satisfies (8)-(16).

In steady-state,

$$
\mathbf{S}_{t+1}=\mathbf{S}_{t}
$$

for all $t$ and $\mathbf{s}_{i} \in I \times E \times A \times B$.

\section{Calibration}

Tables 1 and 2 summarize the model's key parameters, as discussed below.

\subsection{Households}

Utility Function Parameters. The coefficient of relative risk aversion, $\gamma$, is assumed to be 2.0. The number of dependent children at the parents' age $i, n_{i}$, is calculated using the 2001 Survey of Consumer Finances (SCF) as shown in Table 3. The "adult equivalency scale," $\zeta$, is set at $0.6{ }^{10}$ As discussed later, $\beta$ is chosen to hit a target capital-output ratio,

\footnotetext{
${ }^{10}$ Hence, a married couple with two dependent children must consume about 52 percent (i.e., $2^{0.6}=1.517$ ) more than a married couple with no children to attain the same level of utility, ceteris paribus.
} 
Table 2: Other Main Parameters

\begin{tabular}{|c|c|c|c|c|c|}
\hline & & \multirow{3}{*}{$\begin{array}{l}\text { Representative- } \\
\text { Agent Model } \\
\text { without Wage } \\
\text { Shocks }\end{array}$} & \multicolumn{3}{|c|}{$\begin{array}{c}\text { Heterogeneous-Agent Economy } \\
\text { with Wage Shocks }\end{array}$} \\
\hline & & & & \multicolumn{2}{|c|}{$\begin{array}{l}\text { Lower Transi- } \\
\text { tory Shocks to }\end{array}$} \\
\hline & & & & $1 / 2$ & $1 / 5$ \\
\hline Time preference parameter ${ }^{1}$ & $\beta$ & 1.004 & 0.985 & 0.992 & 1.000 \\
\hline Share parameter for consumption ${ }^{2}$ & $\alpha$ & 0.436 & 0.466 & 0.456 & 0.450 \\
\hline Income tax adjustment factor ${ }^{3}$ & $\varphi_{I}$ & 1.000 & 0.818 & 0.847 & 0.874 \\
\hline OASDI benefit adjustment factor 4 & $\varphi_{S S}$ & 1.232 & 1.385 & 1.388 & 1.388 \\
\hline
\end{tabular}

1. The capital-GDP ratio is targeted to be $2.74(r=6.25$ percent) without annuity markets.

2. The average annual working hours are 3414 per married couple when $h_{\max }=8760$.

3. In a heterogeneous-agent economy, the ratio of income tax revenue to GDP is 0.123 .

4. The OASDI budget is assumed to be balanced.

Table 3: Number of People Under Age 18 Living in a Married Household

\begin{tabular}{cccc}
\hline Age cohorts & Number of children & Age cohorts & Number of children \\
\hline $20-24$ & 0.642 & $50-54$ & 0.908 \\
$25-29$ & 1.167 & $55-59$ & 0.562 \\
$30-34$ & 1.451 & $60-64$ & 0.231 \\
$35-39$ & 1.755 & $65-69$ & 0.156 \\
$40-44$ & 1.753 & $70-74$ & 0.055 \\
$45-49$ & 1.439 & $75-$ plus & 0.000 \\
\hline Source: Authors' calculations from the 2001 Survey of Consumer Finances (SCF).
\end{tabular}

producing an interest rate of 6.2 percent in the initial steady state. The maximum working hours of husband and wife, $h_{i}^{\max }$, is set at 8,760 , equal to 12 hours per day per person $\times$ 365 days $\times$ two persons. ${ }^{11}$ A smaller value for $h_{i}^{\max }$ would reduce the effective labor supply elasticity, and tend to reduce the gains from privatization. The parameter $\alpha$ is chosen so that the average working hours of households between ages 20 and 64 equals 3,414 hours in the initial steady-state economy, the average number of hours supplied by married households in the 2001 SCF.

\footnotetext{
${ }^{11}$ The 95th and 99th percentiles of the working hours per married couple of aged 20-64 in the 2001 SCF are 5,280 and 6,375 , respectively.
} 
Table 4: Working Abilities of a Household (in U.S. Dollars per Hour)

\begin{tabular}{rrrrrrrr}
\hline & Percentile & \multicolumn{7}{c}{ Age Cohorts } \\
\cline { 3 - 8 } & & $20-24$ & $25-29$ & $30-34$ & $35-39$ & $40-44$ & $45-49$ \\
\hline$e^{1}$ & $0-20$ th & 3.89 & 5.47 & 6.86 & 6.01 & 7.43 & 5.73 \\
$e^{2}$ & $20-40$ th & 8.35 & 10.11 & 12.38 & 12.27 & 13.90 & 13.14 \\
$e^{3}$ & $40-60$ th & 10.28 & 14.04 & 16.46 & 16.96 & 18.76 & 18.47 \\
$e^{4}$ & $60-80$ th & 12.31 & 17.30 & 21.87 & 22.57 & 25.79 & 25.71 \\
$e^{5}$ & $80-90$ th & 17.47 & 21.58 & 29.37 & 30.19 & 35.37 & 35.56 \\
$e^{6}$ & $90-95$ th & 22.17 & 27.21 & 33.96 & 46.92 & 48.30 & 54.59 \\
$e^{7}$ & $95-99$ th & 29.43 & 36.60 & 43.76 & 81.75 & 96.44 & 97.48 \\
$e^{8}$ & $99-100$ th & 42.31 & 62.29 & 182.78 & 327.65 & 262.03 & 284.00 \\
\hline \multicolumn{7}{c}{ Percentile } & \multicolumn{7}{c}{ Age cohorts } \\
\cline { 3 - 8 } & & $50-54$ & $55-59$ & $60-64$ & $65-69$ & $70-74$ & $75-79$ \\
\hline$e^{1}$ & $0-20$ th & 5.00 & 2.42 & 0.00 & 0.00 & 0.00 & 0.00 \\
$e^{2}$ & $20-40$ th & 13.99 & 10.65 & 3.36 & 0.00 & 0.00 & 0.00 \\
$e^{3}$ & $40-60$ th & 20.95 & 15.60 & 11.00 & 1.92 & 0.00 & 0.00 \\
$e^{4}$ & $60-80$ th & 29.13 & 24.60 & 18.33 & 11.14 & 1.77 & 1.30 \\
$e^{5}$ & $80-90$ th & 40.89 & 34.75 & 29.08 & 19.14 & 10.93 & 10.21 \\
$e^{6}$ & $90-95$ th & 54.11 & 51.62 & 44.41 & 29.99 & 20.66 & 20.88 \\
$e^{7}$ & $95-99$ th & 91.67 & 99.24 & 91.12 & 56.19 & 38.26 & 26.41 \\
$e^{8}$ & $99-100$ th & 282.18 & 333.58 & 555.90 & 244.71 & 193.00 & 86.76 \\
\hline \multicolumn{2}{c}{ Source: Authors' calculations from the 2001 SCF. }
\end{tabular}

Working Ability. The working ability in this calibration corresponds to the hourly wage (labor income per hour) of each household in the $2001 \mathrm{SCF} .^{12}$ The average hourly wage of a married couple (family members \#1 and \#2 in SCF) used in the calibration is calculated by

$$
\text { Hourly Wage }=\frac{\text { Regular and Additional Salaries }(\# 1+\# 2)+\text { Payroll Taxes } / 2}{\max \{\text { Working Hours }(\# 1+\# 2), 2080\}} .
$$

We adjusted the salaries in the numerator by adding imputed payroll taxes paid by their employers, which allows us to levy the entire payroll tax on employees in order to incorporate the payroll tax ceiling. The max operator in the denominator adjusts the hourly wage for a small fraction of households in the SCF with large reported salaries but few reported working hours such as the self-employed.

\footnotetext{
${ }^{12}$ According to Bureau of Labor Statistics data, the average hourly earnings of production workers have increased by 3.8 percent from 2000 to 2001 . Since the 2001 SCF wages correspond to year 2000 while our tax function introduced below is calibrated to the year 2001, we multiply the SCF wages shown in Table 4 by 1.038 to convert the hourly wages in 2000 into growth-adjusted wages in 2001 .
} 
Table 4 shows the eight discrete levels of working abilities of five-year age cohorts. We use a shape-preserving cubic spline interpolation between each five-year age cohort to obtain the working ability for each age cohort. ${ }^{13}$ In the version of our model where we "turn off" the idiosyncratic wage shocks, the hourly wages of the representative household are assumed to be those of the 40-60th percentile households.

Table 4, however, only shows the different potential "wage buckets" by age as well as the proportion of households in each bucket. It does not itself capture the uncertainty over wages. Using the Panel Study of Income Dynamics (PSID), therefore, we estimate Markov transition matrixes that specify the probabilities that a household's wage will move from one level to a different level the next year. Separate transition matrixes were constructed for four age ranges - $20-29,30-39,40-49$, and $50-59$ - in order to capture the possibility that the probabilities themselves might change over the lifecycle. For households aged 60 or older, we used the matrix for ages 50-59. The Appendix reports the matrixes in detail. We check the sensitivity of our simulation results to this specification later in the paper.

Population Growth and Mortality. The population growth rate $\nu$ is set to one percent per year, consistent with Social Security Administration (2001) long-run estimates. The survival rate $\phi_{i}$ at the end of age $i=\{20, \ldots, 109\}$ are the weighted averages of the male and female survival rates as calculated by SSA. The survival rates at the end of age 109 are replaced by zero, thereby capping the maximum length of life. See the Appendix for more details.

\subsection{Production}

Capital and Private Wealth. Capital $K$ is the sum of private fixed assets and government fixed assets. In 2000, private fixed assets were $\$ 21,165$ billion, government fixed assets were $\$ 5,743$ billion, and the public held about $\$ 3,410$ billion of government debt. ${ }^{14}$ Government net wealth, therefore, is set equal to 9.5 percent of total private wealth in the initial steadystate economy. Moreover, the time preference parameter $\beta$ is chosen in each variant of our model explored below so that the capital-GDP ratio in the initial steady state economy is

\footnotetext{
${ }^{13}$ An alternative approach of estimating eight different wage rates for each age would have relied on too few observations.

${ }^{14}$ Source: Department of Commerce, Bureau of Economic Analysis.
} 
2.74 , the empirical value in $2000 .^{15}$

Production Technology. Production takes the Cobb-Douglas form,

$$
F\left(K_{t}, L_{t}\right)=A_{t} K_{t}^{\theta} L_{t}^{1-\theta}
$$

where, recall, $L_{t}$ is the sum of working hours in efficiency units. The capital share of output is given by

$$
\theta=1-\frac{\text { Compensation of Employees }+(1-\theta) \times \text { Proprietors' Income }}{\text { National Income }+ \text { Consumption of Fixed Capital }} .
$$

The value of $\theta$ in 2000 was $0.30{ }^{16}$ The annual per-capita growth rate $\mu$ is assumed to be 1.8 percent, the average rate between 1869 to 1996 (Barro, 1997). Total factor productivity $A$ is set at 0.949 , which normalizes the wage (per efficient labor unit) to unity.

The Depreciation Rate of Fixed Capital. The depreciation rate of fixed capital $\delta$ is chosen by the following steady-state condition,

$$
\delta=\frac{\text { Total Gross Investment }}{\text { Fixed Capital }}-\mu-\nu
$$

In 2000, private gross fixed investment accounted for 17.2 percent of GDP, and government (federal and state) gross investment accounted for 3.3 percent of GDP. ${ }^{17}$ With a capitaloutput ratio of 2.74, the ratio of gross investment to fixed capital is 7.5 percent. Subtracting productivity and population growth rates, the annual depreciation rate is 4.7 percent.

\subsection{The Government}

Income Taxes. Federal income tax and state and local taxes are assumed to be at the level in year 2001 before the passage of the "Economic Growth and Tax Relief Reconciliation Act of 2001" (EGTRRA). Since households in our model are assumed to be married, we use a standard deduction of $\$ 7,600$. However, following Altig et al. (2001), we allow higher income households to itemize deductions when it is more valuable to do so, and we assume

\footnotetext{
${ }^{15}$ Ibid.

${ }^{16}$ Source: Department of Commerce, Bureau of Economic Analysis. The average of $\theta$ in years between 1996 and 2000 is 0.31 .

${ }^{17} \mathrm{ibid}$.
} 
Table 5: Marginal Individual Income Tax Rates in 2001 (Married Household, Filed Jointly)

\begin{tabular}{rrr}
\hline \multicolumn{2}{c}{ Taxable Income } & Marginal Income Tax Rate (\%) \\
\hline$\$ 0-\$ 45,200$ & $15.0 \times \varphi_{I}$ \\
$\$ 45,200-\$ 109,250$ & $28.0 \times \varphi_{I}$ \\
$\$ 109,250-\$ 166,500$ & $31.0 \times \varphi_{I}$ \\
$\$ 166,500-\$ 297,350$ & $36.0 \times \varphi_{I}$ \\
$\$ 297,350-$ & & $39.6 \times \varphi_{I}$ \\
\hline
\end{tabular}

that the value of the itemized deduction increases linearly in the Adjusted Gross Income. ${ }^{18}$ The additional exemption per dependent person is $\$ 2,900$ where the number of dependent children is consistent with Table 3 . Table 5 shows the statutory marginal tax rates before EGTRRA. ${ }^{19}$ As noted earlier, a household's labor income in this calibration includes the imputed payroll tax paid by its employer. Thus, taxable income is obtained by subtracting the employer portion of payroll tax from labor income.

The standard deduction, the personal exemption, and all tax brackets grow with productivity over time so that there is no real bracket creep; this indexing is also needed for the initial economy to be in steady state. Also, since the effective tax rate on capital income is reduced by investment tax incentives, accelerated depreciation and other factors (Auerbach, 1996), the tax function is further adjusted so that the cross-sectional average tax rate on capital income is about 25 percent lower than the average tax on labor income. ${ }^{20}$ In 2000 , the ratio of total individual federal income tax revenue (not including Social Security and Medicare taxes) to GDP was 0.102 and the ratio of corporate income tax to GDP was 0.021 . Each statutory federal income tax rate shown in Table 5, therefore, is multiplied by $\varphi_{I}$ so that tax revenue (including corporate income tax) totals 12.3 percent of GDP in the initial steady state. The adjustment factor is between 0.82 and 0.87 for heterogeneous-agent economies with idiosyncratic wage shocks and 1.0 for the representative-agent economy without wage shocks. State and local income taxes are modeled parsimoniously with a 4.0 percent flat tax

\footnotetext{
${ }^{18}$ In particular, the deduction taken by a household is the greater of the standard deduction and $0.0755 \times$ AGI, or $\max \{\$ 7600,0.0755 \times \mathrm{AGI}\}$.

${ }^{19}$ The key qualitative results reported herein are unaffected if the tax function were instead modeled as net taxes, that is, after substracting transfers indicated in the Statistics of Income.

${ }^{20}$ This relative reduction to the tax rate on capital is commonly used by $\mathrm{CBO}$, and it balances the legal tax preferences given to capital versus the legal tax benefits given to labor, including tax-preferred fringe benefits.
} 
Table 6: Marginal Payroll Tax Rates in 2001

\begin{tabular}{ccc}
\hline Taxable Labor & \multicolumn{2}{c}{ Marginal Tax Rate $(\%)$} \\
\cline { 2 - 3 } Income per Worker & OASDI & HI \\
\hline$\$ 0-\$ 80,400$ & $12.4 \times \varphi_{P}$ & 2.9 \\
$\$ 80,400-$ & $0.0 \times \varphi_{P}$ & 2.9 \\
\hline Note: The payroll tax adjustment factor $\varphi_{P}$ equals $1.0 \mathrm{in}$. \\
the baseline economy.
\end{tabular}

Table 7: OASDI Replacement Rates in 2001

\begin{tabular}{rrr}
\hline \multicolumn{2}{c}{ AIME (b/12) } & Marginal Replacement Rate (\%) \\
\hline$\$ 0-\$ 561$ & - & $90.0 \times \varphi S S$ \\
$\$ 561-\$ 3,381$ & $32.0 \times \varphi S S$ \\
$\$ 3,381-$ & & $15.0 \times \varphi S S$ \\
\hline
\end{tabular}

Note: The OASDI benefit adjustment factor $\varphi_{S S}$ is set so that the OASDI is pay-as-you-go in the baseline economies.

on income above the deduction and exemption levels used at the federal level.

Social Security. The tax rate levied on employees for Old-Age, Survivors, and Disability Insurance (OASDI) is 12.4 percent, and the tax rate for Medicare (HI) is 2.9 percent. In 2001, employee compensation above $\$ 80,400$ was not taxable for OASDI. (See Table 6.)

Social Security benefits are based on each worker's Average Indexed Monthly Earnings (AIME), $b_{i} / 12$, and the replacement rate schedule in the United States. The replacement rates are 90 percent for the first $\$ 561,32$ percent for amounts between $\$ 561$ and $\$ 3,381$, and 15 percent for amounts above $\$ 3,381$. Social Security, therefore, is progressive in that a worker's benefit relative to AIME (the "replacement rate") is decreasing in the AIME.

The U.S. OASDI also pays spousal, survivors' and disability benefits in addition to the standard retirement benefit described above. Indeed, retiree benefits accounted for only 69.1 percent of total OASDI benefits in December 2000. ${ }^{21}$ OASDI benefits, therefore, are adjusted upward by the proportional adjustment factor $\varphi_{S S}$ so that total benefit payments equal total payroll tax revenue. The adjustment factor $\varphi_{S S}$ equals about 1.39 in our model with wage shocks and 1.23 in our model without wage shocks. This adjustment proportionally

\footnotetext{
${ }^{21}$ See Table 5.A1 in Social Security Administration (2001).
} 
distributes non-retiree OASDI payments across retirees.

\section{Policy Experiments}

We simulate a stylized phased-in partial privatization of Social Security that begins in year 1 . Workers immediately start redirecting 50 percent of their payroll tax payments into private saving accounts. As is implicit in most previous work on privatization, assets in the new private accounts are assumed to be perfect substitutes with other private assets, including earning the same market rate of return and being subject to the same income tax schedule, as outlined above. As a result, the new private accounts do not have to be explicitly modeled; the redirected payroll simply augment regular household saving.

Social Security benefits are reduced linearly over time. Households age 66 and older in year 1 receive the current-law (baseline) benefits throughout the rest of their lifetime; households of age 65 in year 1 receive benefits that are 1.25 percent lower than the currentlaw level throughout the rest of lifetime; households of age 64 in year 1 receive benefits 2.5 percent lower than the current law-level, and so on. Households age 25 or younger in year 1, therefore, receive one half of their traditional Social Security benefits when they turn 65 .

Since benefit payments are reduced more slowly than payroll taxes during the transitional period, Social Security faces a cash-flow deficit that we finance with a consumption tax; work by Kotlikoff, Smetters and Walliser (2001) also focused on consumption tax financing as a method of producing the largest macroeconomic gains from privatization. Since changes to the Social Security system will also influence the size of the capital stock and, hence, non-Social Security government receipts, the rest of the government budget is balanced by proportional changes in marginal income tax rates.

We first consider the representative-agent economy without wage shocks (equivalently, with insurable wage shocks) where all households have the wage profile of the 40-60th percentile in Table 4, i.e., lifetime income group $e^{3}$. We then turn to a heterogeneous-agent economy with uninsurable wage shocks. We initially assume that both economies are closed to international capital flows, and that a private annuity market does not exist. 
Table 8: Percent Change in Selected Macro Variables Relative to Baseline

\begin{tabular}{|c|c|c|c|c|c|c|c|c|}
\hline Run \# & Year $t$ & GNP & $\begin{array}{l}\text { National } \\
\text { Wealth }\end{array}$ & $\begin{array}{l}\text { Labor } \\
\text { Supply }\end{array}$ & $\begin{array}{c}\text { Interest } \\
\text { Rate }\end{array}$ & $\begin{array}{l}\text { Wage } \\
\text { Rate }\end{array}$ & $\begin{array}{c}\text { Income } \\
\text { Tax } \\
\text { Rate }^{* 2}\end{array}$ & $\begin{array}{c}\text { Consump- } \\
\text { tion Tax } \\
\text { Rate }\end{array}$ \\
\hline 1 & 1 & 2.4 & 0.0 & 3.4 & 4.2 & -1.0 & -13.4 & 6.5 \\
\hline Representative & 10 & 3.8 & 6.4 & 2.7 & -4.3 & 1.1 & -14.6 & 5.7 \\
\hline Agent without & 20 & 5.4 & 10.9 & 3.1 & -8.7 & 2.2 & -16.6 & 4.3 \\
\hline \multirow[t]{2}{*}{ Wage Shocks ${ }^{* 1}$} & 40 & 8.3 & 17.6 & 4.6 & -13.8 & 3.6 & -20.1 & 1.1 \\
\hline & Long Run & 9.3 & 20.7 & 4.8 & -16.4 & 4.3 & -21.2 & -0.2 \\
\hline 2 & 1 & 1.3 & 0.0 & 1.8 & 2.3 & -0.5 & -5.7 & 5.5 \\
\hline Heterogenous & 10 & 2.5 & 4.3 & 1.7 & -3.0 & 0.7 & -6.6 & 4.8 \\
\hline Agents with & 20 & 4.0 & 8.1 & 2.2 & -6.7 & 1.7 & -8.1 & 3.6 \\
\hline \multirow[t]{2}{*}{ Wage Shocks $* 1$} & 40 & 6.7 & 15.1 & 3.4 & -12.7 & 3.3 & -10.6 & 0.9 \\
\hline & Long Run & 7.8 & 18.7 & 3.5 & -16.0 & 4.2 & -11.3 & -0.2 \\
\hline
\end{tabular}

*1. Closed economy, no private annuity markets, and LSRA is off.

*2. The proportional change in marginal tax rates across all households.

\subsection{Representative-Agent Economy without Wage Shocks}

As shown in Run 1 in Table 8, partial privatization of Social Security in the representativeagent economy increases national wealth by 20.7 percent in the long run compared to the baseline economy. GNP increases by 9.3 percent in the long run, while labor supply increases by 4.8 percent. These large gains are driven by pre-funding a portion of Social Security's liabilities that were previously financed on a pay-as-you-go (unfunded) basis.

Moreover, national wealth and GNP increase throughout the entire transition path. Labor supply initially increases by 3.4 percent in the first year as households reoptimize their lifecycle choices after the policy change. However, labor supply declines slightly between years 1 and 20 after the reform before eventually increasing. The reason for this non-monotonic behavior is two-fold. First, as shown in Table 8, labor supply increases faster than capital during part of the first decade after reform, briefly decreasing the wage rate by about 1 percent. Second, the new temporary consumption tax, which starts at 6.5 percent and comes down over time as Social Security benefits are gradually reduced, discourages labor supply during the transition. ${ }^{22}$

Despite these positive gains to economic variables, not everyone wins from privatization.

\footnotetext{
${ }^{22}$ The consumption tax does not return exactly to zero in the long run due to a larger labor supply interacting with the progressive benefit schedule within the smaller Social Security system that remains after privatization.
} 
Table 9: Change in Welfare per Household (1,000 dollars in 2001)

\begin{tabular}{|c|c|c|c|c|c|c|}
\hline \multirow[b]{2}{*}{ Run \# } & \multirow{2}{*}{$\begin{array}{l}\text { Age in } \\
\text { Year } 1\end{array}$} & \multicolumn{4}{|c|}{$\begin{array}{c}\text { Without LSRA*1 } \\
\text { Select Productivities }\end{array}$} & \multirow{2}{*}{$\begin{array}{c}\text { With LSRA }^{* 2} \\
\text { For all } \\
\text { Productivities }\end{array}$} \\
\hline & & $e^{1}$ & $e^{3}$ & $e^{5}$ & $e^{8}$ & \\
\hline 1 & 79 & - & -7.5 & - & - & 0.0 \\
\hline Representative & 60 & - & -47.4 & - & - & 0.0 \\
\hline Agent without & 40 & - & -60.0 & - & - & 0.0 \\
\hline \multirow[t]{3}{*}{ Wage Shocks } & 20 & - & -16.9 & - & - & 0.0 \\
\hline & 0 & - & 24.6 & - & - & 21.9 \\
\hline & -20 & - & 47.1 & - & - & 21.9 \\
\hline 2 & 79 & -4.8 & -5.7 & -14.7 & -79.3 & 0.0 \\
\hline Heterogenous & 60 & -27.6 & -43.5 & -64.4 & -361.8 & 0.0 \\
\hline Agents with & 40 & -18.7 & -46.7 & -76.4 & -368.4 & 0.0 \\
\hline \multirow[t]{3}{*}{ Wage Shocks } & 20 & 2.2 & -1.5 & -5.2 & -15.5 & 0.0 \\
\hline & 0 & 32.8 & 33.7 & 36.1 & 43.4 & -5.6 \\
\hline & -20 & 52.4 & 56.7 & 63.5 & 84.3 & -5.6 \\
\hline
\end{tabular}

*1. Standard equivalent variations measures.

*2. Value of $\Delta t r$.

As shown for Run 1 in Table 9 ("Without LSRA"), all households alive at the time of the reform (that is, aged 20 or older) are worse off. For example, the age-20 household at the time of policy change loses $\$ 16,900$, as measured by the equivalent variation of an onetime wealth transfer made at the time of the reform. The age- 40 household loses $\$ 60,000$. These losses are mainly caused by the transitional consumption tax, which especially harms middle-aged households that hold a large amount of non-Social Security wealth. ${ }^{23}$ In a closed economy, these households are also hurt by the fall in the interest rate shown in Table $8 .^{24}$

Future households, who pay very little of the transition costs, however, gain substantially from privatization. For example, newborns in Year 1 gain about $\$ 24,600$ per couple while generations born 20 years later gain about $\$ 47,100$. These gains arise mainly from higher wages and from the reduced distortions from payroll taxes. Federal income taxes also decline by 21.2 percent in the long run due to an expanded economy.

However, does privatization actually produce overall efficiency gains, that is, after the "winners" compensate the "losers?" To make this determination, we simulate the same ex-

\footnotetext{
${ }^{23}$ Social Security wealth under law and in our model is protected by inflation, including that caused by consumption taxes.

${ }^{24}$ For example, the welfare loss of a 40 -year old is reduced by half in a small open economy (not shown), where the interest rate does not change.
} 
periment but with an operative Lump-Sum Redistribution Authority (LSRA). ${ }^{25}$ Recall that the LSRA transfers exactly enough wealth to would-be losing households alive at the time of the reform so that their remaining expected lifetime utilities return to their pre-reform levels. These transfers must be financed with borrowing that is financed with the gains to future generations. All net new resources (positive or negative) are then distributed equally to future households (growth adjusted over time). As shown in Table 9, privatization produces about $\$ 21,900$ (in 2001 growth-adjusted dollars) in additional net resources per each future household that enters the economy in year 2 and later. In other words, the 50-percent phased-in privatization does indeed increase efficiency in our deterministic economy setting.

\subsection{Heterogeneous-Agent Economy with Wage Shocks}

Run 2 in Table 8 shows the effects of the same stylized privatization experiment in a more realistic economy with uninsurable wage shocks. Unlike in the deterministic economy, Social Security's progressive benefit formula now shares some wage risks, thereby providing some insurance that is unattainable in the private market. National wealth now increases by 18.7 percent in the long run, but by less than in the representative-agent economy (Run 1) because a portion of private saving in the pre-reform economy is now for precautionary motives, which is less sensitive to changes in Social Security policy. Labor supply increases by 3.5 percent in the long run and GNP is 7.8 percent higher.

Similar to the representative-agent economy, most households alive at the time of the reform are worse off because they have to pay higher taxes to finance the transition. Run 2 in Table 9 shows that relatively high wage (and, hence, wealthier) households tend to be hit the hardest by the consumption tax. For example, a 40-year old in the top one percent of the wage distribution $\left(e^{8}\right)$ at the time of privatization loses $\$ 368,400$. As with Run 1 , future households, however, gain considerably from the lower payroll and income tax rates as well as higher wages. Even households in the lowest 20 percent of the wage distribution $\left(e^{1}\right)$ born 20 years after the reform gain $\$ 52,400$ (in 2001 growth-adjusted dollars). Overall, privatization, though, no longer improves efficiency. After the LSRA returns the welfare

\footnotetext{
${ }^{25}$ To save on space, we don't report the change in macroeconomic variables for the experiments with the LSRA. These tables, however, are available upon request.
} 
of all households to their pre-reform levels, it distributes a negative $\$ 5,600$ to each future household. This loss contrasts sharply with the gain of $\$ 21,900$ in the deterministic economy discussed above.

\subsection{Alternative Experiments in the Heterogeneous-Agent Economy}

In a Small Open Economy. Run 3, reported in Table 10, shows the effect of privatization in the setting of a small open economy where any changes in the capital-labor ratio are nullified immediately by international capital flows. Since interest rates do not decline, national wealth increases by substantially more in the long run relative to the closed economy setting - by almost double - reported earlier in Run 2 (Table 8). The gain in labor supply, though, is smaller since the wage rate does not rise. GNP increases gradually and by 11.5 percent in the long run, compared to only 7.8 percent in Run 2.

Table 11 shows that the welfare losses of households alive at the time of the reform tend to be smaller relative to the closed economy (Run 2, Table 9), mostly due to the fixed interest rate. Furthermore, the gains to future households tend to be a little larger in the small open economy, especially for wealthier households who see the reduction in the rate of return to capital in the closed economy but not in the small open economy. On the whole, it might, therefore, appear at first that privatization in an open economy setting would produce a smaller efficiency loss than in the closed economy. Interestingly, this hunch is incorrect. When the LSRA is operative, Table 11 shows that the efficiency losses are actually slightly larger in the small open economy, equal to $\$ 6,600$ per each future household. The reason is that the LSRA's cost of borrowing is higher in the small open economy setting since the interest rate does not decrease over time after privatization, as in the closed-economy setting.

Perfect Annuity Markets. Thus far, we have assumed private annuity markets do not exist and so, in addition to sharing wage uncertainty, the Social Security system shares longevity uncertainty in a way the private market cannot. It would appear at first glance, therefore, that privatization has a better chance of producing efficiency gains if we instead assumed that a private annuity market is available. Surprisingly, this intuition also turns out to be incorrect.

Run 4 in Table 11 shows that the efficiency losses are actually larger with perfect private 
Table 10: Alternative Experiments in the Heterogenous Agent Economy with Wage Shocks - Percent Change in Selected Macro Variables Relative to Baseline

\begin{tabular}{|c|c|c|c|c|c|c|c|c|}
\hline Run \# & Year $t$ & GNP & $\begin{array}{l}\text { National } \\
\text { Wealth }\end{array}$ & $\begin{array}{l}\text { Labor } \\
\text { Supply }\end{array}$ & $\begin{array}{c}\text { Interest } \\
\text { Rate }\end{array}$ & $\begin{array}{l}\text { Wage } \\
\text { Rate }\end{array}$ & $\begin{array}{c}\text { Income } \\
\text { Tax } \\
\text { Rate }^{* 2}\end{array}$ & $\begin{array}{c}\text { Consump- } \\
\text { tion Tax } \\
\text { Rate }\end{array}$ \\
\hline 3 & 1 & 2.1 & 0.0 & 3.0 & 0.0 & 0.0 & -7.3 & 5.4 \\
\hline Small Open & 10 & 3.6 & 7.3 & 2.0 & 0.0 & 0.0 & -7.5 & 4.9 \\
\hline \multirow{3}{*}{ Economy $^{* 1}$} & 20 & 5.6 & 14.5 & 1.8 & 0.0 & 0.0 & -8.6 & 3.7 \\
\hline & 40 & 9.3 & 27.1 & 1.7 & 0.0 & 0.0 & -10.4 & 1.0 \\
\hline & Long Run & 11.5 & 36.5 & 0.8 & 0.0 & 0.0 & -10.8 & -0.1 \\
\hline 4 & 1 & 1.2 & 0.0 & 1.8 & 2.1 & -0.5 & -5.8 & 5.5 \\
\hline Perfect Annuity & 10 & 2.3 & 4.2 & 1.5 & -3.1 & 0.8 & -6.4 & 4.8 \\
\hline \multirow[t]{3}{*}{ Markets ${ }^{* 1}$} & 20 & 3.5 & 7.4 & 1.9 & -6.0 & 1.6 & -7.6 & 3.7 \\
\hline & 40 & 5.7 & 12.4 & 2.9 & -10.0 & 2.7 & -9.5 & 0.9 \\
\hline & Long Run & 6.4 & 14.4 & 3.2 & -11.7 & 3.1 & -10.1 & -0.2 \\
\hline 5 & 1 & 0.0 & 0.0 & -0.1 & -0.1 & 0.0 & 0.5 & 5.6 \\
\hline Contribution & 10 & 0.7 & 2.2 & 0.1 & -2.5 & 0.6 & -0.4 & 5.0 \\
\hline Matching & 20 & 2.0 & 5.1 & 0.8 & -5.1 & 1.3 & -2.0 & 3.8 \\
\hline \multirow{2}{*}{ Starting at $10 \% * 1$} & 40 & 4.7 & 11.5 & 2.0 & -10.6 & 2.7 & -4.6 & 1.0 \\
\hline & Long Run & 5.9 & 15.1 & 2.1 & -14.0 & 3.6 & -5.6 & -0.2 \\
\hline 6 & 1 & -1.9 & 0.0 & -2.7 & -3.4 & 0.8 & 9.0 & 5.8 \\
\hline Contribution & 10 & -1.5 & -0.5 & -2.0 & -1.8 & 0.4 & 8.0 & 5.3 \\
\hline Matching & 20 & -0.5 & 1.2 & -1.2 & -3.0 & 0.8 & 6.5 & 4.0 \\
\hline \multirow[t]{2}{*}{ Starting at $20 \% * 1$} & 40 & 2.2 & 7.2 & 0.1 & -8.2 & 2.1 & 3.3 & 1.0 \\
\hline & Long Run & 3.4 & 11.0 & 0.3 & -12.0 & 3.1 & 2.1 & -0.1 \\
\hline 7 & 1 & 0.5 & 0.0 & 0.7 & 0.9 & -0.2 & -4.2 & 7.1 \\
\hline More Progressive & 10 & 1.3 & 2.2 & 0.8 & -1.7 & 0.4 & -5.1 & 6.4 \\
\hline S.S. Bend Points & 20 & 2.6 & 5.3 & 1.5 & -4.5 & 1.1 & -6.6 & 5.0 \\
\hline \multirow[t]{2}{*}{$120 / 32 / 10 \% * 1$} & 40 & 5.5 & 12.2 & 2.7 & -10.5 & 2.7 & -9.2 & 1.8 \\
\hline & Long Run & 6.7 & 16.1 & 2.9 & -14.2 & 3.7 & -10.1 & 0.4 \\
\hline 8 & 1 & -0.2 & 0.0 & -0.3 & -0.3 & 0.1 & -3.0 & 8.9 \\
\hline More Progressive & 10 & 0.1 & 0.3 & 0.1 & -0.3 & 0.1 & -3.6 & 8.3 \\
\hline S.S. Bend Points & 20 & 1.3 & 2.6 & 0.7 & -2.2 & 0.6 & -5.1 & 6.6 \\
\hline \multirow[t]{2}{*}{$150 / 32 / 10 \% * 1$} & 40 & 4.3 & 9.4 & 2.1 & -8.2 & 2.1 & -8.0 & 2.8 \\
\hline & Long Run & 5.5 & 13.4 & 2.3 & -12.1 & 3.1 & -8.9 & 1.2 \\
\hline
\end{tabular}

*1. Each Run represents one change in assumption relative to Run 2, i.e., the changes are not cumulative.

$* 2$. The proportional change in marginal tax rates across all households. 
Table 11: Change in Welfare per Household (1,000 dollars in 2001)

\begin{tabular}{|c|c|c|c|c|c|c|}
\hline \multirow[b]{2}{*}{ Run \# } & \multirow{2}{*}{$\begin{array}{l}\text { Age in } \\
\text { Year } 1\end{array}$} & \multicolumn{4}{|c|}{$\begin{array}{c}\text { Without LSRA*1 } \\
\text { Select Productivities }\end{array}$} & \multirow{2}{*}{$\begin{array}{c}\text { With LSRA }{ }^{* 2} \\
\text { For all } \\
\text { Productivities }\end{array}$} \\
\hline & & $e^{1}$ & $e^{3}$ & $e^{5}$ & $e^{8}$ & \\
\hline 3 & 79 & -4.8 & -5.6 & -14.4 & -75.7 & 0.0 \\
\hline Small Open & 60 & -25.8 & -40.1 & -54.6 & -184.8 & 0.0 \\
\hline \multirow[t]{4}{*}{ Economy $^{* 3}$} & 40 & -15.3 & -37.3 & -57.1 & -155.5 & 0.0 \\
\hline & 20 & 1.1 & 1.6 & 3.5 & 15.9 & 0.0 \\
\hline & 0 & 23.6 & 29.9 & 39.2 & 73.0 & -6.6 \\
\hline & -20 & 39.8 & 50.1 & 64.2 & 112.5 & -6.6 \\
\hline 4 & 79 & -4.3 & -5.1 & -12.7 & -63.1 & 0.0 \\
\hline Perfect Annuity & 60 & -21.5 & -33.4 & -47.9 & -296.9 & 0.0 \\
\hline \multirow[t]{4}{*}{ Markets $^{* 3}$} & 40 & -13.1 & -32.4 & -51.5 & -288.5 & 0.0 \\
\hline & 20 & 4.9 & 3.3 & 2.5 & 1.1 & 0.0 \\
\hline & 0 & 24.6 & 26.6 & 30.2 & 43.5 & -7.2 \\
\hline & -20 & 36.2 & 40.7 & 47.7 & 72.3 & -7.2 \\
\hline 5 & 79 & -5.3 & -6.3 & -16.5 & -91.2 & 0.0 \\
\hline Contribution & 60 & -28.3 & -40.8 & -68.3 & -558.4 & 0.0 \\
\hline Matching & 40 & -9.3 & -48.8 & -86.8 & -471.4 & 0.0 \\
\hline \multirow[t]{3}{*}{ Starting at $10 \% * 3$} & 20 & 11.6 & 7.1 & -4.3 & -32.1 & 0.0 \\
\hline & 0 & 40.4 & 40.4 & 34.9 & 24.1 & -4.4 \\
\hline & -20 & 60.5 & 63.7 & 62.7 & 65.7 & -4.4 \\
\hline 6 & 79 & -6.0 & -7.1 & -19.0 & -107.6 & 0.0 \\
\hline Contribution & 60 & -29.4 & -38.5 & -74.0 & -825.8 & 0.0 \\
\hline Matching & 40 & -0.2 & -53.1 & -103.8 & -614.9 & 0.0 \\
\hline \multirow[t]{3}{*}{ Starting at $20 \% * 3$} & 20 & 19.3 & 13.4 & -6.5 & -56.8 & 0.0 \\
\hline & 0 & 45.9 & 44.6 & 30.3 & -4.3 & -9.9 \\
\hline & -20 & 66.6 & 68.5 & 58.7 & 38.8 & -9.9 \\
\hline 7 & 79 & 34.2 & 32.9 & 20.7 & -69.3 & 0.0 \\
\hline More Progressive & 60 & 7.1 & 6.1 & -25.2 & -469.9 & 0.0 \\
\hline S.S. Bend Points & 40 & -13.2 & -41.1 & -76.4 & -407.2 & 0.0 \\
\hline \multirow[t]{3}{*}{$120 / 32 / 10 \% * 3$} & 20 & -4.9 & -9.8 & -15.3 & -32.6 & 0.0 \\
\hline & 0 & 25.8 & 26.0 & 26.9 & 28.3 & -0.1 \\
\hline & -20 & 47.9 & 51.6 & 57.6 & 74.2 & -0.1 \\
\hline 8 & 79 & 76.5 & 75.2 & 61.9 & -45.6 & 0.0 \\
\hline More Progressive & 60 & 47.8 & 59.0 & 25.7 & -548.5 & 0.0 \\
\hline S.S. Bend Points & 40 & -9.8 & -37.7 & -75.5 & -442.6 & 0.0 \\
\hline \multirow[t]{3}{*}{$150 / 32 / 10 \% * 3$} & 20 & -13.4 & -19.4 & -26.9 & -50.5 & 0.0 \\
\hline & 0 & 17.6 & 16.8 & 16.3 & 12.0 & 2.7 \\
\hline & -20 & 41.7 & 45.1 & 50.1 & 63.0 & 2.7 \\
\hline
\end{tabular}

*1. Standard equivalent variations measures.

*2. Value of $\Delta t r$.

*3. Each Run represents one change in assumption relative to Run 2, i.e., the changes are not cumulative. 
annuity markets than without (Run 2). In particular, each household loses $\$ 7,200$, compared to $\$ 5,600$ shown earlier (Run 2, Table 9) without an annuity market. Privatization with perfect private annuities leads to only a 14.4 percent increase in national wealth in the long run (Table 10), compared to a 18.7 percent increase without a private annuity market (Run 2, Table 8). The reason is that households increase their precautionary savings in Run 2 after privatization as the annuity insurance provided by Social Security is reduced; in contrast, households can rely more on the private annuity insurance market rather than precautionary savings in Run 4. The smaller amount of precautionary savings in Run 4 produces larger efficiency losses for three reasons: (i) the LSRA must borrow at a relatively higher interest rate; (ii) income taxes are higher since there is less capital and labor income; and (iii) the interest elasticity of saving is higher, increasing the role that falling interest rates have on discouraging additional saving.

Contribution Matching. The pre-reform Social Security system is progressive by giving households with a lower average index of pre-retirement wages a larger Social Security benefit relative to their pre-retirement wages, that is, a larger "replacement rate." This progressivity provides some insurance against wage uncertainty. To be sure, the privatized experiment considered above preserves some progressivity by reducing benefits proportionally only by half in the long run - the poor still get a larger replacement rate. But a proportional reduction in benefits still reduces progressivity; for example, reducing all benefits by 100 percent would eliminate progressivity.

Run 5, therefore, considers privatization with a progressive contribution match. In particular, working households with low levels of labor income receive a fairly generous match equal to 10 percent of their earnings. This matching rate declines linearly to zero as labor income approaches $\$ 60,000$, which is slightly above the median household income in the model economy. ${ }^{26}$ While ensuing Social Security deficits continue to be financed with a consumption tax, the contribution match is financed each year by increasing the marginal income tax rates proportionally across all households; the key qualitative results would be unchanged if the consumption tax were used instead. As before, income tax rates are changed

\footnotetext{
${ }^{26}$ This matching schedule is equivalent with the marginal labor income tax of -10 percent at $\$ 0$ of labor income, 0 percent at $\$ 30,000,10$ percent at $\$ 60,000$, and 0 percent for labor income above $\$ 60,000$.
} 
so that the rest of government budget is balanced throughout the transition path.

As shown in Run 5 in Table 10, privatization with contribution matching increases national wealth, GNP and labor supply throughout the transition path compared to the prereform baseline economy. However, the long-run increases in national wealth, labor supply, and GNP are smaller relative to the case without contribution matching (Run 2 in Table 8) since the match must be financed with a distorting income tax. In the long run, GNP increases by only 5.9 percent, compared to 7.8 percent without the match.

The welfare gains for Run 5 reported in Table 11 show that contribution matching tends to improve the welfare of poorer households relative to Run 2 without the match. Whereas the poorest household born in the future gains $\$ 52,400$ without the match, they gain $\$ 60,500$ with the match. Not surprising, the richest households, however, are worse off since they don't receive any of the match but must help finance it; they gained $\$ 84,300$ without the match in the long run but only $\$ 65,700$ with the match. With the LSRA, privatization still leads to efficiency losses, equal to about $\$ 4,400$ (in 2001 growth-adjusted dollars) per future household. But this loss is smaller than the $\$ 5,600$ loss without the match.

Run 6 doubles the starting match rate from 10 percent at zero wage income to 20 percent. As before, this match declines linearly to zero as labor income approaches $\$ 60,000$. Table 11 shows that, with the LSRA, this more generous match produces efficiency losses equal to $\$ 9,900$ per future household, which is larger in magnitude relative to the 10 percent match and even Run 2 without any match. This non-monotonic behavior in efficiency losses is due to the trade-off between risk sharing and labor supply distortions: some match is beneficial but is dominated by distortions at higher tax rates. ${ }^{27}$ In fact, there is no match rate that allows privatization to produced efficiency gains. Moreover, several alternative designs of contribution matching performed even worse. ${ }^{28}$

\footnotetext{
${ }^{27}$ These distortions arise from both the income tax used to finance the match as well as the effective marginal tax rates caused by the match itself.

${ }^{28}$ For example, a proportional match for all households performed worse because, while eliminating implicit marginal tax rates in the phase-out range, it enhanced the income tax distortions since more revenue is needed. We also considered financing the phased-out match with a negative match on those with above-average incomes. Although potentially more efficient at redistribution than an income tax, as the poor are not financing their own match, it also performed worse. Labor supply tends to be fairly elastic in our model whereas the savings elasticity is relatively low with precautionary saving.
} 
Progressive Benefit Schedule. Run 7 takes a different approach to maintaining some progressivity after privatization. It immediately increases the progressivity of the Social Security benefit that remains after privatization by raising the replacement rate of the lowest wage income bracket from 90 percent to 120 percent while reducing the replacement rate of the highest wage income bracket from 15 percent to 10 percent. Run 8 is even more aggressive in redistribution by raising the replacement rate of the lowest wage income bracket to 150 percent. Table 11 shows that this approach is very effective at protecting the welfare of the poor at the time of reform as well as reducing efficiency losses. Now, privatization reduces efficiency by only $\$ 100$ per future household under the LSRA in Run 8 . But privatization actually increases efficiency by $\$ 2,700$ per future household in Run 8 . Increasing the progressivity of the smaller Social Security system that remains after privatization is more efficient than contribution matching because a considerable amount of redistribution can be accomplished with less distortion to labor supply, that is, with smaller effective tax rates at the margin. In particular, whereas contribution matching is based on the labor income in any given year, Social Security's progressive benefit is based on a household's lifetime earnings, which is harder to change.

\subsection{Alternative Assumptions of Transitory Shocks and Persistence}

A key assumption in our model is the size of the transitory working ability shocks and their persistence. Recall that we constructed the age-working ability schedule from the 2001 Survey of Consumer Finances (SCF) and the transition matrices from the 1989-92 Panel Study of Income Dynamics (PSID). To deal with possible measurement errors, our benchmark Markov transition matrixes are calculated after taking three-year moving averages of workers' hourly wages. This ad hoc treatment reduces the size of transitory wage shocks in the original data by about one-third. Floden and Lindé (2001), however, persuasively argue that measurement error in the PSID might be as large as the size of the real fluctuation. Thus, although we have already "smoothed away" some of that error by focusing on three-year moving averages, the transitory shocks in our model might still be too large.

Run 9 shown in Tables 12 and 13 show the economic and welfare effects, respectively, of privatization when the transitory shocks are reduced to only half of their previous values we 
Table 12: Alternative Transitory Shocks - Percent Change in Selected Macro Variables Relative to Baseline

\begin{tabular}{ccrrrrrrr}
\hline Run \# & Year $t$ & GNP & $\begin{array}{c}\text { National } \\
\text { Wealth }\end{array}$ & $\begin{array}{c}\text { Labor } \\
\text { Supply }\end{array}$ & $\begin{array}{c}\text { Interest } \\
\text { Rate }\end{array}$ & $\begin{array}{r}\text { Wage } \\
\text { Rate }\end{array}$ & $\begin{array}{c}\text { Income } \\
\text { Tax } \\
\text { Rate*2 }\end{array}$ & $\begin{array}{c}\text { Consump- } \\
\text { tion Tax } \\
\text { Rate }\end{array}$ \\
\hline 9 & 1 & 1.5 & 0.0 & 2.2 & 2.7 & -0.7 & -6.3 & 5.6 \\
$\frac{1}{2}$ Transitory & 10 & 3.0 & 5.0 & 2.1 & -3.4 & 0.8 & -7.5 & 4.9 \\
Shocks*1 & 20 & 4.6 & 9.4 & 2.6 & -7.7 & 1.9 & -9.2 & 3.7 \\
& 40 & 7.5 & 16.6 & 3.8 & -13.7 & 3.6 & -11.7 & 0.9 \\
& Long Run & 8.7 & 20.4 & 4.0 & -17.1 & 4.5 & -12.6 & -0.3 \\
\hline 10 & 1 & 1.6 & 0.0 & 2.3 & 2.8 & -0.7 & -6.4 & 5.7 \\
$\frac{1}{5}$ Transitory & 10 & 3.1 & 5.4 & 2.2 & -3.8 & 0.9 & -7.8 & 5.0 \\
Shocks*1 & 20 & 4.9 & 10.1 & 2.7 & -8.3 & 2.1 & -9.6 & 3.7 \\
& 40 & 7.9 & 17.4 & 4.0 & -14.3 & 3.7 & -12.4 & 0.9 \\
& Long Run & 9.1 & 21.4 & 4.2 & -17.8 & 4.7 & -13.4 & -0.3 \\
\hline
\end{tabular}

*1. Each Run represents one change in assumption relative to Run 2, i.e., the changes are not cumulative.

*2. The proportional change in marginal tax rates across all households.

used in the main calibration. Run 10 goes even further: it reduces the shocks to only one-fifth of the values under the main calibration. National wealth increases by 20.4 percent in the long run in Run 9, compared to 18.7 percent for Run 2. However, notice that the efficiency losses actually increase to $\$ 8,200$ per future household (relative to a $\$ 5,600$ loss in Run 2) under the LSRA. This counter-intuitive result can be explained by the fact that a reduction in transitory shocks also increases the persistence of any shock. As a result, the effect of any negative shock becomes more permanent, potentially increasing the value of the risk sharing in the former Social Security system. ${ }^{29}$

In the limit, however, the model collapses to one with no wage uncertainty if the transitory shocks are eliminated. In Run 10, the transitory shocks are reduced to one-fifth of their benchmark levels and in this case, privatization produces a smaller efficiency loss, compared to Run 9, equal to about $\$ 5,800$ per future household. These two policy experiments show that changes in the amount of wage uncertainty have a non-monotonic impact on efficiency gains.

\footnotetext{
${ }^{29}$ We benefited from a helpful conversation with Dirk Krueger on this point.
} 
Table 13: Change in Welfare per Household (3) (1,000 dollars in 2001)

\begin{tabular}{|c|c|c|c|c|c|c|}
\hline \multirow[b]{2}{*}{ Run \# } & \multirow{2}{*}{$\begin{array}{l}\text { Age in } \\
\text { Year } 1\end{array}$} & \multicolumn{4}{|c|}{$\begin{array}{c}\text { Without LSRA*2 } \\
\text { Select Productivities }\end{array}$} & \multirow{2}{*}{$\begin{array}{c}\text { With LSRA }^{* 3} \\
\text { For all } \\
\text { Productivities }\end{array}$} \\
\hline & & $e^{1}$ & $e^{3}$ & $e^{5}$ & $e^{8}$ & \\
\hline 9 & 79 & -4.2 & -5.1 & -13.8 & -116.5 & 0.0 \\
\hline$\frac{1}{2}$ Transitory & 60 & -25.6 & -44.4 & -65.4 & -388.0 & 0.0 \\
\hline \multirow[t]{4}{*}{ Shocks*1 } & 40 & -28.0 & -58.6 & -81.4 & -419.1 & 0.0 \\
\hline & 20 & -7.2 & -12.9 & -15.4 & -13.1 & 0.0 \\
\hline & 0 & 18.7 & 21.6 & 31.6 & 73.0 & -8.2 \\
\hline & -20 & 35.2 & 43.6 & 61.1 & 127.4 & -8.2 \\
\hline 10 & 79 & -4.8 & -6.1 & -13.1 & -171.5 & 0.0 \\
\hline \multirow{5}{*}{$\begin{array}{l}\frac{1}{5} \text { Transitory } \\
\text { Shocks*1 }^{*}\end{array}$} & 60 & -26.3 & -48.4 & -68.6 & -411.4 & 0.0 \\
\hline & 40 & -40.5 & -73.7 & -84.3 & -408.6 & 0.0 \\
\hline & 20 & -19.5 & -26.9 & -22.6 & 16.9 & 0.0 \\
\hline & 0 & 0.6 & 8.6 & 35.8 & 161.5 & -5.8 \\
\hline & -20 & 13.6 & 30.3 & 69.7 & 241.0 & -5.8 \\
\hline
\end{tabular}

*1. Each Run represents one change in assumption relative to Run 2.

*2. Standard equivalent variations measures.

*3. Value of $\Delta t r$.

\section{Concluding Remarks}

This paper investigated whether a stylized Social Security privatization generates efficiency gains or losses in the presence of an overlapping-generations economy with elastic labor supply and idiosyncratic wage shocks and longevity uncertainty. We found that the privatization of Social Security produces efficiency gains in a representative-agent economy without wage shocks (or, equivalently, if these shocks are insurable). In a heterogeneousagent economy with idiosyncratic and uninsurable wage shocks, however, the overall efficiency of the economy is reduced by our stylized privatization since the existing Social Security system provides a valuable source of risk sharing through its progressive benefit formula. This result was fairly robust to a wide range of model considerations: (i) the degree of openness of the economy; (ii) allowing the availability of actuarially-fair private annuities; (iii) the introduction of various risk-sharing mechanisms after privatization; and (iv) sharply reducing the size of transitory wage shocks. Only in the case in which the benefit replacement rate of the lowest bracket was increased to 150 percent from 90 percent did we find efficiency gains. Rather interestingly, privatization performs relatively better in a closed 
economy where the rate of return falls as capital is accumulated; surprisingly, privatization even performs relatively better when private annuity markets do not exist. Furthermore, matching the contribution of poorer workers can actually do more harm than good, whereas increasing the progressivity of the Social Security system that remains works well.

One of the possible limitations of our model is that it does not distinguish by various demographic groups, including race and gender. There is some evidence, for example, that black Americans do not live as long as non-blacks, even after controlling for differences in earnings. Blacks are also less likely to be married at the point of retirement and, therefore, less likely to qualify for a spousal benefit. ${ }^{30}$ In contrast, women have a higher life expectancy than males, and they might also face a higher effective marginal tax rate on their contributions if they are the household's secondary earner. Incorporating these additional sources of heterogeneity would possibly change the welfare implications of this paper.

\footnotetext{
${ }^{30}$ See, for example, Gustman and Steinmeier (2001).
} 


\section{Appendices}

\section{A Transition Matrixes and Survival Rates}

Markov Transition Matrixes. The Markov transition matrixes of working ability are constructed for four age groups-20-29, 30-39, 40-49, and 50-59-from the hourly wages in the PSID individual data 1990, 91, 92, and 93. To reduce the size of transitory shocks, possibly caused by measurement errors, the transition matrix of each age group is calculated with transition probabilities from the average wages between 1989 and 91 to the average wages between of 1990 and 92. For households aged 60 or older, we used the matrix for ages 50-59.

\begin{tabular}{|c|c|c|c|c|c|c|c|c|}
\hline \multirow{8}{*}{$\Gamma_{i \in\{20, \ldots, 29\}}=$} & 0.7601 & 0.2101 & 0.0289 & 0.0000 & 0.0009 & 0.0000 & 0.0000 & 0.0000 \\
\hline & 0.1919 & 0.6171 & 0.1635 & 0.0221 & 0.0054 & 0.0000 & 0.0000 & 0.0000 \\
\hline & 0.0406 & 0.1546 & 0.5976 & 0.1794 & 0.0153 & 0.0068 & 0.0028 & 0.0029 \\
\hline & 0.0063 & 0.0181 & 0.1787 & 0.6723 & 0.1128 & 0.0118 & 0.0000 & 0.0000 \\
\hline & 0.0018 & 0.0000 & 0.0506 & 0.2524 & 0.5792 & 0.0995 & 0.0165 & 0.0000 \\
\hline & 0.0000 & 0.0000 & 0.0244 & 0.0000 & 0.2744 & 0.5719 & 0.1293 & 0.0000 \\
\hline & 0.0010 & 0.0000 & 0.0000 & 0.0000 & 0.0372 & 0.1937 & 0.6646 & 0.1035 \\
\hline & 0.0000 & 0.0000 & 0.0000 & 0.0000 & 0.0000 & 0.0000 & 0.4727 & 0.5273 \\
\hline \multirow{8}{*}{$\Gamma_{i \in\{30, \ldots, 39\}}=$} & 0.8537 & 0.1332 & 0.0082 & 0.0049 & 0.0000 & 0.0000 & 0.0000 & 0.0000 \\
\hline & 0.1283 & 0.6837 & 0.1744 & 0.0129 & 0.0007 & 0.0000 & 0.0000 & 0.0000 \\
\hline & 0.0175 & 0.1723 & 0.6788 & 0.1269 & 0.0000 & 0.0045 & 0.0000 & 0.0000 \\
\hline & 0.0005 & 0.0109 & 0.1314 & 0.7374 & 0.1014 & 0.0144 & 0.0040 & 0.0000 \\
\hline & 0.0000 & 0.0000 & 0.0144 & 0.2008 & 0.7016 & 0.0728 & 0.0104 & 0.0000 \\
\hline & 0.0000 & 0.0000 & 0.0000 & 0.0460 & 0.1874 & 0.6182 & 0.1484 & 0.0000 \\
\hline & 0.0000 & 0.0000 & 0.0000 & 0.0298 & 0.0011 & 0.2008 & 0.7147 & 0.0536 \\
\hline & 0.0000 & 0.0000 & 0.0000 & 0.0000 & 0.0000 & 0.0000 & 0.2145 & 0.7855 \\
\hline \multirow{8}{*}{$\Gamma_{i \in\{40, \ldots, 49\}}=$} & 0.8561 & 0.1371 & 0.0068 & 0.0000 & 0.0000 & 0.0000 & 0.0000 & 0.0000 \\
\hline & 0.1301 & 0.7275 & 0.1222 & 0.0145 & 0.0057 & 0.0000 & 0.0000 & 0.0000 \\
\hline & 0.0000 & 0.1111 & 0.7145 & 0.1588 & 0.0000 & 0.0156 & 0.0000 & 0.0000 \\
\hline & 0.0000 & 0.0179 & 0.1484 & 0.6992 & 0.1221 & 0.0124 & 0.0000 & 0.0000 \\
\hline & 0.0000 & 0.0000 & 0.0162 & 0.2548 & 0.6594 & 0.0696 & 0.0000 & 0.0000 \\
\hline & 0.0252 & 0.0257 & 0.0000 & 0.0000 & 0.1702 & 0.6744 & 0.1045 & 0.0000 \\
\hline & 0.0000 & 0.0000 & 0.0000 & 0.0000 & 0.0000 & 0.0933 & 0.8366 & 0.0701 \\
\hline & 0.1496 & 0.0000 & 0.0000 & 0.0000 & 0.0000 & 0.0000 & 0.1308 & 0.7196 \\
\hline \multirow{8}{*}{$\Gamma_{i \in\{50, \ldots, 78\}}=$} & 0.8249 & 0.1629 & 0.0000 & 0.0122 & 0.0000 & 0.0000 & 0.0000 & 0.0000 \\
\hline & 0.1552 & 0.6754 & 0.1694 & 0.0000 & 0.0000 & 0.0000 & 0.0000 & 0.0000 \\
\hline & 0.0200 & 0.0997 & 0.7643 & 0.1052 & 0.0108 & 0.0000 & 0.0000 & 0.0000 \\
\hline & 0.0000 & 0.0620 & 0.0663 & 0.8079 & 0.0559 & 0.0079 & 0.0000 & 0.0000 \\
\hline & 0.0000 & 0.0000 & 0.0000 & 0.1492 & 0.7194 & 0.1314 & 0.0000 & 0.0000 \\
\hline & 0.0000 & 0.0000 & 0.0000 & 0.0000 & 0.2942 & 0.6239 & 0.0819 & 0.0000 \\
\hline & 0.0000 & 0.0000 & 0.0000 & 0.0000 & 0.0000 & 0.1024 & 0.8573 & 0.0403 \\
\hline & 0.0000 & 0.0000 & 0.0000 & 0.0000 & 0.0000 & 0.0000 & 0.1613 & 0.8387 \\
\hline
\end{tabular}

where $\Gamma_{i}(j, k)=\pi\left(e_{i+1}=e_{i+1}^{k} \mid e_{i}=e_{i}^{j}\right)$. 
Survival Rates of Households. The survival rates $\phi_{i}$ at the end of age $i=\{20, \ldots, 109\}$ are the weighted averages of males and females and calculated from the period life table (Table 4.C6) in Social Security Administration (2001). The survival rates at the end of age 109 are replaced by zero.

Table 14: Survival Rates in 1998 in the United States (Weighted Average of Males and Females)

\begin{tabular}{cccccccccc}
\hline Age & $\begin{array}{c}\text { Survival } \\
\text { Rate }\end{array}$ & Age & $\begin{array}{c}\text { Survival } \\
\text { Rate }\end{array}$ & $\begin{array}{c}\text { Age } \\
\text { Rutvival }\end{array}$ & $\begin{array}{c}\text { Age } \\
\text { Survival } \\
\text { Rate }\end{array}$ & $\begin{array}{c}\text { Age } \\
\text { Rate }\end{array}$ \\
\hline 20 & 0.999104 & 40 & 0.997966 & 60 & 0.989315 & 80 & 0.937788 & 100 & 0.676630 \\
21 & 0.999057 & 41 & 0.997807 & 61 & 0.988305 & 81 & 0.931527 & 101 & 0.658554 \\
22 & 0.999027 & 42 & 0.997640 & 62 & 0.987134 & 82 & 0.924684 & 102 & 0.639355 \\
23 & 0.999018 & 43 & 0.997451 & 63 & 0.985773 & 83 & 0.917252 & 103 & 0.618962 \\
24 & 0.999023 & 44 & 0.997252 & 64 & 0.984249 & 84 & 0.909150 & 104 & 0.597297 \\
25 & 0.999034 & 45 & 0.997027 & 65 & 0.982548 & 85 & 0.900275 & 105 & 0.574281 \\
26 & 0.999040 & 46 & 0.996778 & 66 & 0.980759 & 86 & 0.890541 & 106 & 0.549828 \\
27 & 0.999033 & 47 & 0.996514 & 67 & 0.979000 & 87 & 0.879882 & 107 & 0.523850 \\
28 & 0.999006 & 48 & 0.996237 & 68 & 0.977325 & 88 & 0.868264 & 108 & 0.496251 \\
29 & 0.998962 & 49 & 0.995938 & 69 & 0.975647 & 89 & 0.855676 & 109 & 0.000000 \\
30 & 0.998911 & 50 & 0.995603 & 70 & 0.973769 & 90 & 0.842119 & & \\
31 & 0.998857 & 51 & 0.995222 & 71 & 0.971613 & 91 & 0.827606 & & \\
32 & 0.998796 & 52 & 0.994797 & 72 & 0.969264 & 92 & 0.812154 & & \\
33 & 0.998727 & 53 & 0.994324 & 73 & 0.966703 & 93 & 0.795784 & & \\
34 & 0.998651 & 54 & 0.993795 & 74 & 0.963868 & 94 & 0.778522 & & \\
35 & 0.998564 & 55 & 0.993198 & 75 & 0.960661 & 95 & 0.761075 & & \\
36 & 0.998466 & 56 & 0.992534 & 76 & 0.957027 & 96 & 0.743640 & & \\
37 & 0.998358 & 57 & 0.991818 & 77 & 0.952967 & 97 & 0.726432 & & \\
38 & 0.998240 & 58 & 0.991051 & 78 & 0.948449 & 98 & 0.709688 & & \\
39 & 0.998111 & 59 & 0.990216 & 79 & 0.943423 & 99 & 0.693653 & & \\
\hline
\end{tabular}

Source: Authors' calculations from the Table 4.C6, Social Security Administration (2001).

\section{B The Computation of Equilibria}

The algorithm to solve the model for a steady-state equilibrium and an equilibrium transition path is similar to those in Conesa and Krueger (1999), Nishiyama (2002), and Nishiyama and Smetters (2004).

\section{B.1 The Discretization of the State Space}

The state of a household is $\mathbf{s}_{i}=\left(i, e_{i}, a_{i}, b_{i}\right) \in I \times E \times A \times B$, where $I=\{20, \ldots, 109\}$, $E=\left[e^{\min }, e^{\max }\right], A=\left[a^{\min }, a^{\max }\right]$, and $B=\left[b^{\min }, b^{\max }\right]$. To compute an equilibrium, the state space of a household is discretized as $\hat{\mathbf{s}}_{i} \in I \times \hat{E}_{i} \times \hat{A} \times \hat{B}$, where $\hat{E}_{i}=\left\{e_{i}^{1}, e_{i}^{2}, \ldots, e_{i}^{N_{e}}\right\}$, $\hat{A}=\left\{a^{1}, a^{2}, \ldots, a^{N_{a}}\right\}$, and $\hat{B}=\left\{b^{1}, b^{2}, \ldots, b^{N_{b}}\right\}$. For all these discrete points, the model computes the optimal decision of households, $\mathbf{d}\left(\hat{\mathbf{s}}_{i}, \mathbf{S}_{t} ; \mathbf{\Psi}_{t}\right)=\left(c_{i}(),. h_{i}(),. a_{i+1}().\right) \in$ 
$\left(0, c^{\max }\right] \times\left[0, h_{i}^{\max }\right] \times A$, the marginal values, $\frac{\partial}{\partial a} v\left(\hat{\mathbf{s}}_{i}, \mathbf{S}_{t} ; \mathbf{\Psi}_{t}\right)$ and $\frac{\partial}{\partial b} v\left(\hat{\mathbf{s}}_{i}, \mathbf{S}_{t} ; \boldsymbol{\Psi}_{t}\right)$, and the values $v\left(\hat{\mathbf{s}}_{i}, \mathbf{S}_{t} ; \boldsymbol{\Psi}_{t}\right)$, given the expected factor prices and policy variables. ${ }^{31}$

To find the optimal end-of-period wealth, the model uses the Euler equation and bilinear interpolation (with respect to $a$ and $b$ ) of marginal values at the beginning of the next period. ${ }^{32}$ In a heterogeneous-agent economy, $N_{e}, N_{a}$, and $N_{b}$ are 8,57 , and 8 , respectively. In a representative-agent economy, the numbers of grid points are 1,61 , and 6 , respectively. ${ }^{33}$

\section{B.2 A Steady-State Equilibrium}

The algorithm to compute a steady-state equilibrium is as follows. Let $\boldsymbol{\Psi}$ denote the timeinvariant government policy rule $\boldsymbol{\Psi}=\left(W_{L S}, W_{G}, C_{G}, \tau_{I}(),. \tau_{P}(),. \tau_{C}, \operatorname{tr}_{S S}\left(\hat{\mathbf{s}}_{i}\right), \operatorname{tr}_{L S}\left(\hat{\mathbf{s}}_{i}\right)\right)$.

1. Set the initial values of factor prices $\left(r^{0}, w^{0}\right)$, accidental bequests $q^{0}$, the policy variables $\left(W_{L S}^{0}, C_{G}^{0}, \tau_{C}^{0}\right)$, and the parameters $\left(\varphi_{I}^{0}, \varphi_{S S}^{0}\right)$ of policy functions $\left(\tau_{I}(),. \operatorname{tr}_{S S}\left(\hat{\mathbf{s}}_{i}\right)\right)$ if these are determined endogenously. ${ }^{34}$

2. Given $\Omega^{0}=\left(r^{0}, w^{0}, q^{0}, W_{L S}^{0}, C_{G}^{0}, \tau_{C}^{0}, \varphi_{I}^{0}, \varphi_{S S}^{0}\right)$, find the decision rule of a household $\mathbf{d}\left(\hat{\mathbf{s}}_{i} ; \boldsymbol{\Psi}, \boldsymbol{\Omega}^{0}\right)$ for all $\hat{\mathbf{s}}_{i} \in I \times \hat{E}_{i} \times \hat{A} \times \hat{B} .^{35}$

(a) For age $i=109$, find the decision rule $\mathbf{d}\left(\hat{\mathbf{s}}_{109} ; \boldsymbol{\Psi}, \boldsymbol{\Omega}^{0}\right)$. Since the survival rate $\phi_{109}=0$, the end-of-period wealth $a_{i+1}\left(\hat{\mathbf{s}}_{109} ;.\right)=0$ for all $\hat{\mathbf{s}}_{109}$. Compute consumption and working hours $\left(c_{i}\left(\hat{\mathbf{s}}_{109} ;.\right), h_{i}\left(\hat{\mathbf{s}}_{109} ;.\right)\right)$ and, then, marginal values $\frac{\partial}{\partial a} v\left(\hat{\mathbf{s}}_{109} ; \boldsymbol{\Psi}, \boldsymbol{\Omega}^{0}\right)$ and values $v\left(\hat{\mathbf{s}}_{109} ; \boldsymbol{\Psi}, \boldsymbol{\Omega}^{0}\right)$ for all $\hat{\mathbf{s}}_{109}{ }^{36}$

(b) For age $i=108, \ldots, 20$, find the decision rule $\mathbf{d}\left(\hat{\mathbf{s}}_{i} ; \boldsymbol{\Psi}, \boldsymbol{\Omega}^{0}\right)$, marginal values $\frac{\partial}{\partial a} v\left(\hat{\mathbf{s}}_{i} ; \boldsymbol{\Psi}, \boldsymbol{\Omega}^{0}\right)$, and values $v\left(\hat{\mathbf{s}}_{i} ; \boldsymbol{\Psi}, \boldsymbol{\Omega}^{0}\right)$ for all $\hat{\mathbf{s}}_{i}$, using $\frac{\partial}{\partial a} v\left(\hat{\mathbf{s}}_{i+1} ; \boldsymbol{\Psi}, \boldsymbol{\Omega}^{0}\right)$ and $\frac{\partial}{\partial b} v\left(\hat{\mathbf{s}}_{i+1} ; \boldsymbol{\Psi}, \boldsymbol{\Omega}^{0}\right)$ recursively.

i. Set the initial guess of $a_{i+1}^{0}\left(\hat{\mathbf{s}}_{i} ;.\right)$.

ii. Given $a_{i+1}^{0}\left(\hat{\mathbf{s}}_{i} ;.\right)$, compute $\left(c_{i}\left(\hat{\mathbf{s}}_{i} ;.\right), h_{i}\left(\hat{\mathbf{s}}_{i} ;.\right)\right)$, using $\frac{\partial}{\partial b} v\left(\hat{\mathbf{s}}_{i+1} ; \boldsymbol{\Psi}, \boldsymbol{\Omega}^{0}\right)$. Plug these into the Euler equation with $\frac{\partial}{\partial a} v\left(\hat{\mathbf{s}}_{i+1} ; \mathbf{\Psi}, \boldsymbol{\Omega}^{0}\right)$.

\footnotetext{
${ }^{31}$ Because the marginal value with respect to historical earnings, $\frac{\partial}{\partial b} v\left(\hat{\mathbf{s}}_{i}, \mathbf{S}_{t} ; \boldsymbol{\Psi}_{t}\right)$, is difficult to obtain analytically, it is approximated by $\left(v\left(., b^{j+1}, \mathbf{S}_{t} ; \mathbf{\Psi}_{t}\right)-v\left(., b^{j}, \mathbf{S}_{t} ; \mathbf{\Psi}_{t}\right)\right) /\left(b^{j+1}-b^{j}\right)$ where $j=1,2, \ldots, N_{b}$.

${ }^{32}$ The marginal values with respect to wealth, $\frac{\partial}{\partial a} v\left(\hat{\mathbf{s}}_{i}, \mathbf{S}_{t} ; \boldsymbol{\Psi}_{t}\right)$, are used in the Euler equation to obtain optimal savings, the marginal values with respect to historical earnings, $\frac{\partial}{\partial b} v\left(\hat{\mathbf{s}}_{i}, \mathbf{S}_{t} ; \boldsymbol{\Psi}_{t}\right)$, are used in the marginal rate of substitution condition of consumption for leisure to obtain optimal working hours, and the values, $v\left(\hat{\mathbf{s}}_{i}, \mathbf{S}_{t} ; \mathbf{\Psi}_{t}\right)$, are used to calculate welfare changes measured by compensating and equivalent variations in wealth.

${ }^{33}$ The grid points on $A$ and $B$ are not equally spaced. In a heterogeneous-agent economy, $\hat{A}$ ranges from $-\$ 271,000$ to $\$ 33,825,000$ (in 2001 growth-adjusted dollars) and $\hat{B}$ ranges from $\$ 8,000$ to $\$ 80,400$. In a representative-agent economy, $\hat{A}$ and $\hat{B}$ range from $-\$ 333,000$ to $\$ 1,573,000$ and from $\$ 8,000$ to $\$ 80,400$, respectively.

${ }^{34}$ If we find the capital-labor ratio, both $r$ and $w$ are calculated from the given production function and depreciation rate. In this paper, the endogenous policy variables are $C_{G}$ and $\varphi_{S S}$ in baseline economies, and $\tau_{C}, \varphi_{I}$, $\operatorname{tr}_{L S}\left(\hat{\mathbf{s}}_{i}\right)$, and $W_{L S}$ in policy experiments.

${ }^{35}$ In the steady-state economy, the decision rule of a household $\mathbf{d}\left(\hat{\mathbf{s}}_{i} ; \boldsymbol{\Psi}, \boldsymbol{\Omega}^{0}\right)$ is not a function of the aggregate state of economy $\hat{\mathbf{S}}=\left(x\left(\hat{\mathbf{s}}_{i}\right), W_{L S}, W_{G}\right)$. The measure of household $x\left(\hat{\mathbf{s}}_{i}\right)$ is determined uniquely by the steady-state condition, and the government's wealth $W_{G}$ is determined by the policy rule $\Psi$.

${ }^{36}$ The marginal value with respect to historical earnings, $\frac{\partial}{\partial b} v\left(\hat{\mathbf{s}}_{i} ; \boldsymbol{\Psi}, \boldsymbol{\Omega}^{0}\right)$, is zero when $i>60$ in this paper.
} 
iii. If the Euler error is sufficiently small, then stop. Otherwise, update $a_{i+1}^{0}\left(\hat{\mathbf{s}}_{i} ;\right.$.) and return to Step ii.

3. Find the steady-state measure of households $x\left(\hat{\mathbf{s}}_{i} ; \mathbf{\Omega}^{0}\right)$ using the decision rule obtained in Step 2. This computation is done forward from age 20 to age 109. Repeat this step to iterate $q$ for $q^{1}$.

4. Compute new factor prices $\left(r^{1}, w^{1}\right)$, accidental bequests $q^{1}$, the policy variables $\left(W_{L S}^{1}\right.$, $\left.C_{G}^{1}, \tau_{C}^{1}\right)$, and the parameters $\left(\varphi_{I}^{1}, \varphi_{S S}^{1}\right)$ of policy functions.

5. Compare $\boldsymbol{\Omega}^{1}=\left(r^{1}, w^{1}, q^{1}, W_{L S}^{1}, C_{G}^{1}, \tau_{C}^{1}, \varphi_{I}^{1}, \varphi_{S S}^{1}\right)$ with $\boldsymbol{\Omega}^{0}$. If the difference is sufficiently small, then stop. Otherwise, update $\Omega^{0}$ and return to Step 2.

\section{B.3 An Equilibrium Transition Path}

Assume that the economy is in the initial steady state in period 0 , and that the new policy schedule $\boldsymbol{\Psi}_{1}$, which was not expected in period 0 , is announced at the beginning of period 1 , where $\boldsymbol{\Psi}_{1}=\left\{W_{L S, t+1}, W_{G, t+1}, C_{G, t}, \tau_{I, t}(.), \tau_{P, t}(.), \tau_{C, t}, \operatorname{tr}_{S S, t}\left(\hat{\mathbf{s}}_{i}\right), \operatorname{tr}_{L S, t}\left(\hat{\mathbf{s}}_{i}\right)\right\}_{t=1}^{\infty}$. Let $\hat{\mathbf{S}}_{1}=\left(x_{1}\left(\hat{\mathbf{s}}_{i}\right), W_{L S, 1}, W_{G, 1}\right)$ be the state of the economy at the beginning of period 1 . The state of the economy $\hat{\mathbf{S}}_{1}$ is usually equal to that of the initial steady state. The algorithm to compute a transition path to a new steady-state equilibrium (thereafter, final steady-state equilibrium) is as follows.

1. Choose a sufficiently large number, $T$, such that the economy is said to reach the new steady state within $T$ periods. Set the initial guess, $\boldsymbol{\Omega}_{1}^{0}=\left\{r_{s}^{0}, w_{s}^{0}, q_{s}^{0}, W_{L S, s}^{0}, \tau_{C, s}^{0}\right.$, $\left.\varphi_{I, s}^{0}\right\}_{s=1}^{T}$, on factor prices, accidental bequests, and the policy variables. Because there are no aggregate productivity shocks in this model, a time series $\boldsymbol{\Omega}_{t}=\left\{r_{s}^{0}, w_{s}^{0}, q_{s}^{0}\right.$, $\left.W_{L S, s}^{0}, \tau_{C, s}^{0}, \varphi_{I, s}^{0}\right\}_{s=t}^{T}$ is deterministic, and each household perfectly foresees $\boldsymbol{\Omega}_{t}$ based on the information $\hat{\mathbf{S}}_{t}$ in an equilibrium. Since $\hat{\mathbf{S}}_{t}$ is in a household decision rule only to make the household expect $\Omega_{t}$ rationally, in the computation, we can avoid the “curse of dimensionality" by replacing $\mathbf{d}\left(\hat{\mathbf{s}}_{i}, \hat{\mathbf{S}}_{t} ; \boldsymbol{\Psi}_{t}\right)$ with $\mathbf{d}\left(\hat{\mathbf{s}}_{i} ; \boldsymbol{\Psi}_{t}, \boldsymbol{\Omega}_{t}\right)$.

2. Given $W_{L S, T}$, find the final steady-state decision rule $\mathbf{d}\left(\hat{\mathbf{s}}_{i} ; \boldsymbol{\Psi}_{T}, \boldsymbol{\Omega}_{T}^{0}\right)$, marginal values, $\frac{\partial}{\partial a} v\left(\hat{\mathbf{s}}_{i} ; \boldsymbol{\Psi}_{T}, \boldsymbol{\Omega}_{T}^{0}\right)$, and values $v\left(\hat{\mathbf{s}}_{i} ; \mathbf{\Psi}_{T}, \boldsymbol{\Omega}_{T}^{0}\right)$ for all $\hat{\mathbf{s}}_{i} \in I \times \hat{E}_{i} \times \hat{A} \times \hat{B}$. (See the algorithm for a steady-state equilibrium.)

3. For period $t=T-1, T-2, \ldots, 1$, based on the guess, $\boldsymbol{\Omega}_{t}^{0}$, find backward the decision rule $\mathbf{d}\left(\hat{\mathbf{s}}_{i} ; \boldsymbol{\Psi}_{t}, \boldsymbol{\Omega}_{t}^{0}\right)$, marginal values $\frac{\partial}{\partial a} v\left(\hat{\mathbf{s}}_{i} ; \boldsymbol{\Psi}_{t}, \boldsymbol{\Omega}_{t}^{0}\right)$, and values $v\left(\hat{\mathbf{s}}_{i} ; \boldsymbol{\Psi}_{t}, \boldsymbol{\Omega}_{t}^{0}\right)$ for all $\hat{\mathbf{s}}_{i} \in I \times \hat{E}_{i} \times \hat{A} \times \hat{B}$, using the next period marginal values $\frac{\partial}{\partial a} v\left(\hat{\mathbf{s}}_{i+1} ; \boldsymbol{\Psi}_{t+1}, \boldsymbol{\Omega}_{t+1}^{0}\right)$ and values $v\left(\hat{\mathbf{s}}_{i+1} ; \boldsymbol{\Psi}_{t+1}, \boldsymbol{\Omega}_{t+1}^{0}\right)$ recursively.

4. For period $t=1,2, \ldots, T-1$, compute forward $\left(r_{t}^{0}, w_{t}^{0}, q_{t}^{0}, W_{L S, t}^{0}, \tau_{C, t}^{0}, \varphi_{I, t}^{0}\right)$ and the measure of households $x_{t+1}\left(\hat{\mathbf{s}}_{i}\right)$, using the decision rule $\mathbf{d}\left(\hat{\mathbf{s}}_{i} ; \boldsymbol{\Psi}_{t}, \boldsymbol{\Omega}_{t}^{0}\right)$ obtained in Step 3 and using the state of economy $\hat{\mathbf{S}}_{t}=\left(x_{t}\left(\hat{\mathbf{s}}_{i}\right), W_{L S, t}, W_{G, t}\right)$ recursively.

5. Compare $\Omega_{t}^{1}$ with $\Omega_{t}^{0}$. If the difference is sufficiently small, then stop. Otherwise, update $\Omega_{t}^{0}$ and return to Step 2 . 


\section{B.4 The Lump-Sum Redistribution Authority}

When the Lump-Sum Redistribution Authority (LSRA) is assumed, the following computation is added to the iteration process.

1. For period $t=T, T-1, \ldots, 2$, compute the lump-sum transfers to newborn households $\operatorname{tr}_{C V}\left(\hat{\mathbf{s}}_{20} ; \mathbf{\Psi}_{t}, \boldsymbol{\Omega}_{t}^{0}\right)$ to make those households as well off as under the pre-reform economy.

(a) Set the initial value of lump-sum transfers $\operatorname{tr}_{C V}\left(\hat{\mathbf{s}}_{20} ; \boldsymbol{\Psi}_{t}, \boldsymbol{\Omega}_{t}^{0}\right)$ to newborn households.

(b) Given $\operatorname{tr}_{C V}\left(\hat{\mathbf{s}}_{20} ; \mathbf{\Psi}_{t}, \boldsymbol{\Omega}_{t}^{0}\right)$, find the decision rule of newborn households $\mathbf{d}\left(\hat{\mathbf{s}}_{20}\right.$; $\left.\boldsymbol{\Psi}_{t}, \boldsymbol{\Omega}_{t}^{0}\right)$ and values $v\left(\hat{\mathbf{s}}_{20} ; \boldsymbol{\Psi}_{t}, \boldsymbol{\Omega}_{t}^{0}\right)$.

(c) Find the compensating variation in wealth $\Delta \operatorname{tr}_{C V}\left(\hat{\mathbf{s}}_{20} ; \Psi_{t}, \boldsymbol{\Omega}_{t}^{0}\right)$ to make those households indifferent from the baseline economy. (The initial wealth of newborn households is assumed to be zero since they do not receive any bequests.) If the absolute value of $\Delta \operatorname{tr}_{C V}\left(\hat{\mathbf{s}}_{20} ; \mathbf{\Psi}_{t}, \boldsymbol{\Omega}_{t}^{0}\right)$ is sufficiently small, then go to Step (d). Otherwise, update $\operatorname{tr}_{C V}\left(\hat{\mathbf{s}}_{20} ; \boldsymbol{\Psi}_{t}, \boldsymbol{\Omega}_{t}^{0}\right)$ by adding $\Delta \operatorname{tr}_{C V}\left(\hat{\mathbf{s}}_{20} ; \boldsymbol{\Psi}_{t}, \boldsymbol{\Omega}_{t}^{0}\right)$ and return to Step (b).

(d) Set the lump-sum transfers $\operatorname{tr}_{L S, t}\left(\hat{\mathbf{s}}_{20}\right)=\operatorname{tr}_{C V}\left(\hat{\mathbf{s}}_{20} ; \mathbf{\Psi}_{t}, \boldsymbol{\Omega}_{t}^{0}\right)+\Delta t r$ where an additional lump-sum transfer $\Delta t r$ is precalculated, and find the decision rule of newborn households $\mathbf{d}\left(\hat{\mathbf{s}}_{20} ; \boldsymbol{\Psi}_{t}, \boldsymbol{\Omega}_{t}^{0}\right)$.

2. For period $t=1$, compute the lump-sum transfers to all current households $\operatorname{tr}_{C V}\left(\hat{\mathbf{s}}_{i} ; \Psi_{t}\right.$ $\left.\Omega_{t}^{0}\right)$ to make those households as much better off as the pre-reform economy. The procedure is similar to Step 1. Set the lump-sum transfers $\operatorname{tr}_{L S, 1}\left(\hat{\mathbf{s}}_{i}\right)=\operatorname{tr}_{C V}\left(\hat{\mathbf{s}}_{i} ; \mathbf{\Psi}_{t}, \boldsymbol{\Omega}_{t}^{0}\right)$.

3. Compute an additional lump-sum transfer $\Delta t r$ to newborn households so that the net present value of all transfers becomes zero. Compute the LSRA wealth, $\left\{W_{L S, t}^{1}\right\}_{t=1}^{T}$, which will be used to calculate national wealth. Recompute $\Delta t r$ and $\left\{W_{L S, t}^{1}\right\}_{t=1}^{T}$ using new interest rates $\left\{r_{t}\right\}_{t=1}^{T}$. 


\section{References}

[1] Altig, David, Alan Auerbach, Laurence Kotlikoff, Kent Smetters, and Jan Walliser (2001). "Simulating Fundamental Tax Reform in the United States." American Economic Review, 91, 3: 574-595.

[2] Auerbach, Alan (1996). “Tax Reform, Capital Allocation, Efficiency and Growth.” In H. Aaron and W. Gale, Editors, Economic Effects of Fundamental Tax Reform. Brookings Institution Press: Washington, D.C.

[3] Auerbach, Alan and Laurence Kotlikoff (1987). Dynamic Fiscal Policy, Cambridge University Press.

[4] Barro, Robert J. (1997). Macroeconomics (5th edition). The MIT Press: Cambridge, Mass.

[5] Breyer, Friedrich (1989). “On the Intergenerational Pareto Efficiency on Pay-as-you-go Financed Pension Systems.” Journal of Institutional and Theoretical Economics, 145, 4: 643-58.

[6] Conesa, Juan and Dirk Krueger (1999). "Social Security Reform with Heterogeneous Agents." Review of Economic Dynamics, 2, 4: 757-795.

[7] De Nardi, Mariacristina, Selahattin İmrohoroğlu, and Thomas J. Sargent (1999). "Projected U.S. Demographics and Social Security." Review of Economic Dynamics, 2, 3: 575-615.

[8] Diamond, Peter A. and Peter R. Orszag (2003). Saving Social Security: A Balanced Approach. Brookings Institution Press: Washington, D.C.

[9] Feldstein, Martin. "Would Privatizing Social Security Raise Economic Welfare?" NBER Working Paper \#5281, 1995.

[10] Floden, Martin and Jesper Lindé (2001). "Idiosyncratic Risk in the United States and Sweden: Is There a Role for Government Insurance?” Review of Economic Dynamics, 4, 2: 406-37. 
[11] Geanakoplos, John, Olivia S. Mitchell and Stephen P. Zeldes (1998). "Would a Privatized Social Security System Really Pay a Higher Rate of Return?” In D. Arnold, M. Graetz, and A. Munnell, Editors, Framing the Social Security Debate: Values, Politics and Economics, 137-57. Brookings Institution Press: Washington, D.C.

[12] Gustman, Alan L. and Thomas L. Steinmeier (2001). "How Effective Is Redistribution under the Social Security Benefit Formula?" Journal of Public Economics, 82, 1: 1-28

[13] İmrohoroğlu, Ayşe and Selahattin İmrohoroğlu, and Douglas Joines (1995). "A Life Cycle Analysis of Social Security." Economic Theory, 6, 1: 83-114.

[14] Kotlikoff, Laurence J., Kent Smetters, Jan Walliser (2001). "Finding a Way Out of America's Demographic Dilemma.” NBER Working Paper 8258.

[15] Mariger, Randall (1999). "Social Security Privatization: What Are the Issues?" National Tax Journal, 52, 4: 783-802

[16] Murphy, Kevin and Finis Welch (1998). "Perspectives on the Social Security Crisis and Proposed Solutions." American Economic Review, 88, 2: 142-50.

[17] Nishiyama, Shinichi (2002). "Bequests, Inter Vivos Transfers, and Wealth Distribution.” Review of Economic Dynamics, 5, 4: 892-931.

[18] Nishiyama, Shinichi (2004). "Analyzing an Aging Population-A Dynamic General Equilibrium Approach.” Working Paper 2004-3, Congressional Budget Office.

[19] Nishiyama, Shinichi and Kent Smetters (2004). "Consumption Taxes and Economic Efficiency with Idiosyncratic Wage Shocks.” Mimeo, Congressional Budget Office and University of Pennsylvania

[20] Shiller, Robert (1999). "Social Security and Institutions for Intergenerational, Intragenerational and International Risk Sharing." Carnegie-Rochester Conference Series on Public Policy, 50, 99: 165-204.

[21] Social Security Administration (2001). Social Security Bulletin: Annual Statistical Supplement, available at http://www.ssa.gov/statistics/supplement/2001/index.html. 